\title{
REFLEXÕES SOBRE ECONOMIA E RELIGIÃO: SEUS PRINCIPAIS PENSADORES E A IGREJA CATÓLICA BRASILEIRA
}

\section{RONALDO ZANDONÁ CORREIA}

Dissertação apresentada à Escola Superior de Agricultura "Luiz de Queiroz", Universidade de São Paulo, para obtenção do título de Mestre em Ciências, Área de Concentração: Economia Aplicada.

P I R A C I C A B A

Estado de São Paulo - Brasil

Setembro - 2003 


\title{
REFLEXÕES SOBRE ECONOMIA E RELIGIÃO: SEUS PRINCIPAIS PENSADORES E A IGREJA CATÓLICA BRASILEIRA
}

\author{
RONALDO ZANDONÁ CORREIA \\ Bacharel em Ciências Econômicas
}

Orientador: Prof. Dr. PEDRO CARVALHO DE MELLO

Dissertação apresentada à Escola Superior de Agricultura "Luiz de Queiroz", Universidade de São Paulo, para obtenção do título de Mestre em Ciências, Área de Concentração: Economia Aplicada.

P I R A C I C A B A

Estado de São Paulo - Brasil

Setembro - 2003 


\section{Dados Internacionais de Catalogação na Publicação (CIP)} DIVISÃO DE BIBLIOTECA E DOCUMENTAÇÃO - ESALQ/USP

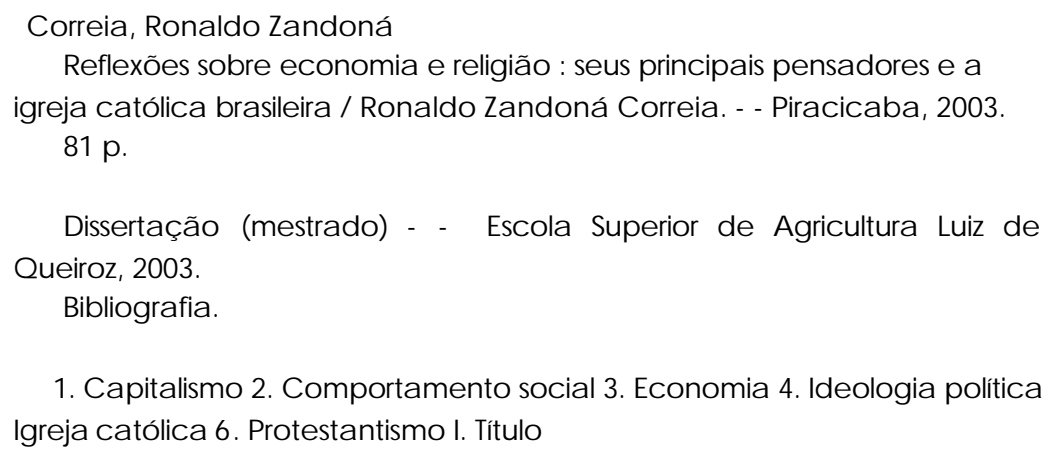

1. Capitalismo 2. Comportamento social 3. Economia 4. Ideologia política Igreja católica 6. Protestantismo I. Título 


\section{AGRADECIMENTOS}

A elaboração desta dissertação dependeu de muito trabalho solitário. No entanto, dependeu também da ajuda e do apoio de muitas pessoas, sem as quais a tarefa seria muito mais difícil. Dessa forma, gostaria de registrar aqui os meus agradecimentos a essas pessoas:

- ao professor e orientador Dr. Pedro Carvalho de Mello, que, além de orientar, deu total apoio à elaboração deste trabalho, que trata de um assunto controverso e difícil;

- aos professores Dr. Alexandre Lahóz Mendonça de Barros, Dr. Antonio Ribeiro de Almeida Jr., Dr. Carlos José Caetano Bacha, pelas valiosas críticas e sugestões apresentadas;

- ao CNPQ, pelo apoio financeiro;

- à minha mãe, ao meu pai e à minha irmã, que sempre estiveram do meu lado, apoiando e dando suporte para que este trabalho fosse viabilizado;

- à minha noiva, que compreendeu a importância deste trabalho para mim e deu total apoio em todos os momentos; 
- aos funcionários e aos professores da Esalq, do Departamento de Economia, Administração e Sociologia, pelas contribuições e ensinamentos;

- aos colegas de pós: Alexandre, André, Lucílio, Joaquim, Julcemar, Paulo, Silvio, Tiziu, pelos momentos alegres e difíceis desfrutados juntos;

- a todos aqueles que diretamente ou indiretamente contribuíram para o êxito deste trabalho. 


\section{SUMÁRIO}

Página

LISTA DE TABELAS .......................................................................... vii

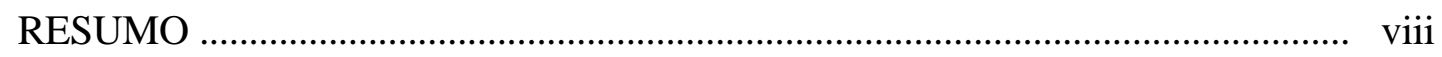

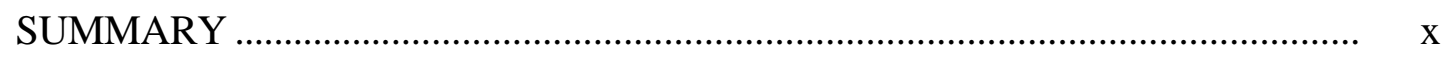

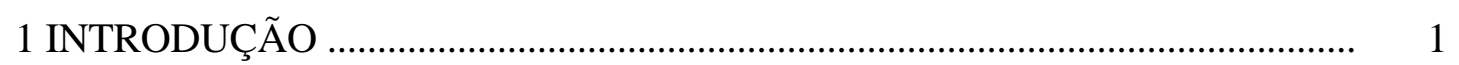

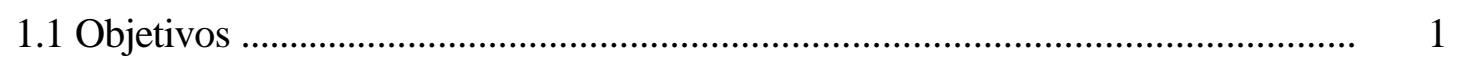

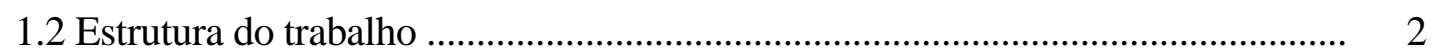

2 METODOLOGIA _...................................................................................... 4

3 ECONOMIA E RELIGIÃO: UM ASSUNTO ABRANGENTE ............................. 6

3.1 A inter-relação entre economia e religião: de John Stuart Mill à

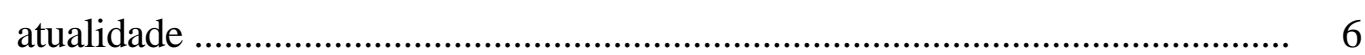

3.1.1 Prováveis motivos que incentivaram a Reforma Protestante ............................ 21

3.2 A tese da secularização e o desenvolvimento econômico ....................................... 24

3.3 Linhas de pesquisa sobre o tema "economia e religião" ....................................... 31

4 A RELAÇÃO DA IGREJA CATÓLICA BRASILEIRA COM ALGUMAS QUESTÕES SECULARES ........................................................ 35

4.1 A transição do sistema monárquico para o republicano e a Igreja

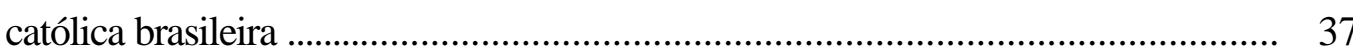

4.1.1 Motivos que levaram ao rompimento entre o Estado republicano e a Igreja católica no Brasil ..................................................................................... 37

4.1.2 A relação entre o Estado brasileiro e a Igreja católica ..................................... 40 
4.2 A concorrência direta e a indireta …............................................................ 47

4.2.1 O aumento na concorrência direta ................................................................. 47

4.2.1.1 O aumento na concorrência direta e a contribuição das idéias de Ekelund ..... 51

4.2.2 O aumento na concorrência indireta ........................................................... 53

$4.3 \mathrm{O}$ estímulo ao sacerdócio católico .................................................................... 54

4.4 Questões de cunho financeiro e a igreja católica .................................................... 61

5 A SITUAÇÃO ATUAL DA IGREJA CATÓLICA BRASILEIRA ......................... 70

5.1 A redução no número de fiéis: contribuição para a discussão atual ....................... 70

6 OBSERVAÇÕES FINAIS ........................................................................... 74

REFERÊNCIAS BIBLIOGRÁFICAS ........................................................... 78 


\section{LISTA DE TABELAS}

Página

1 Evolução do percentual de urbanização e de pessoas sem religião

2 O pensamento de alguns estudiosos sobre a influência que algumas religiões exercem sobre o capitalismo

3 Distribuição percentual da população, segundo a religião, no Brasil ...................... 46

4 Proporção população clero ........................................................................... 57

5 Comparação do número de sacerdotes católicos com o de oficiantes protestantes

6 Comparação do número de locais de culto da Igreja católica e das Igrejas protestantes 


\title{
REFLEXÕES SOBRE ECONOMIA E RELIGIÃO: SEUS PRINCIPAIS PENSADORES E A IGREJA CATÓLICA BRASILEIRA
}

\author{
Autor: RONALDO ZANDONÁ CORREIA \\ Orientador: Prof. Dr. PEDRO CARVALHO DE MELLO
}

\section{RESUMO}

O presente trabalho inicia com a elaboração de uma ampla revisão bibliográfica sobre o tema economia e religião, inclusive analisando trabalhos empíricos recentes que pretendem testar as idéias de Weber, como a da secularização e a da relação entre o desenvolvimento capitalista e o Protestantismo. Essa revisão constatou que a tese de Weber tem se mostrado consistente, apesar de algumas falhas, ou seja, a religiosidade diminui à medida que a sociedade evolui e o protestantismo teve um papel importante, sim, no desenvolvimento do capitalismo moderno. Após essa ampla revisão bibliográfica, que serviu para amadurecer o conhecimento sobre o assunto em questão, este trabalho passa a enfocar seu objetivo principal, que é analisar o comportamento da Igreja católica brasileira, como instituição, frente a questões seculares, principalmente de cunho econômico, político e cultural. Para isso, são analisados o comportamento da Igreja católica frente ao processo de transição do Império para a República, o impacto do aumento da concorrência direta e indireta sobre a Igreja católica brasileira, ao longo do 
século XX, a situação do sacerdócio católico e seu impacto sobre a Igreja católica, assim como o impacto de questões financeiras sobre essa instituição. No geral, toda essa análise apresenta fortes indícios de que questões seculares de cunho econômico, político e cultural acabam influenciando amplamente essa instituição. Com isso, pode-se observar que não apenas questões doutrinárias influenciam essa instituição. Por último, analisa-se a situação atual da Igreja católica e apresentam-se possíveis motivos de a Igreja católica brasileira ter perdido expressiva quantidade de fiéis, ao longo dos últimos vinte anos. 


\title{
CONSIDERATIONS ABOUT ECONOMY AND RELIGION: THE MAIN PHILOSOPHERS AND THE BRASILIAN CATHOLIC CHURCH
}

\author{
Author: RONALDO ZANDONÁ CORREIA \\ Adviser: Prof. Dr. PEDRO CARVALHO DE MELLO
}

\section{SUMMARY}

The present work begins with a broad bibliography review about economy and religion, analyzing recent empirical works that intend to test Weber's ideas, like the secularization and the relation between capitalistic development and the protestantism. This review evidenced that Weber's thesis has been shown consistent, although it has some shortcomings. The consistency refers to the fact that religiosity diminishes as the society develop, and to the fact that the protestantism played an important role in the development of the modern capitalism. After this broad bibliography review, that served to mature the knowledge about the subject in discussion, this work starts to focus his main objective, that consists in analyzing the behavior of the brazilian catholic church, as an institution, vis a vis secular matters (economical, political and cultural mainly). To achieve this objective, it was analyzed the behavior of the catholic church in the process of transition from the Empire to the Republic. It was also analyzed the impact of the increase of the direct and indirect competition that the brazilian catholic church faced in the XX century, and it was analyzed the situation of the catholic priesthood and the impact of it in the catholic church, as well as the impact of financial matters in the same institution. Through the analysis of all these points, it could be observed that not only 
doctrine matters influences this institution. Lastly, it was analyzed the actual situation of the brazilian catholic church and exposed the likely reasons that may be driving this institution to lose an expressively sum of followers in the last twenty years. 


\section{INTRODUÇÃO}

\subsection{Objetivo}

O tema que pretendemos abordar passa pela questão dos vínculos entre economia e religião. Não é um assunto novo, já no século XIX era abordado por John Stuart Mill e depois, mais profundamente, no início do século XX, por Max Weber. Apesar de tanto tempo de discussão, continua sendo um assunto bastante controverso, que dificilmente será esgotado, hajam vista a sua amplitude e a sua complexidade.

Embora já bastante estudado por economistas estrangeiros, trata-se de um assunto pouco abordado por economistas brasileiros. Essa informação é facilmente confirmada, ao analisar-se a bibliografia deste trabalho, composta quase totalmente por economistas estrangeiros. Dentre os estudiosos brasileiros, parece que a preocupação com o tema ficou concentrada nos teólogos e nos historiadores.

Devido à amplitude e à complexidade do tema, focamos como objetivo analisar o comportamento da Igreja católica brasileira, como instituição, frente a questões seculares, principalmente de cunho econômico, político e cultural.

Para atingir esse objetivo, será elaborada uma ampla revisão bibliográfica sobre o assunto em questão, que se prestará a estruturar uma massa crítica de conhecimento sobre o tema, aspecto extremamente importante para se fazer uma análise profunda e isenta sobre o assunto. Essa revisão bibliográfica deve ser encarada como contribuição para a produção 
científica brasileira sobre o tema, haja vista que a mesma tem negligenciado a importância dele. Na revisão, analisam-se os principais trabalhos sobre economia e religião, de John Stuart Mill a autores atuais, como Ekelund e Barro, passando, inclusive, por alguns estudos feitos por teólogos. Esses trabalhos se preocupam com diferentes aspectos do assunto "economia e religião", tais como secularização e influência sobre o desenvolvimento capitalista.

Para atingir o objetivo deste trabalho, será feita uma análise do comportamento da Igreja católica brasileira frente a acontecimentos seculares, como, por exemplo, a mudança no regime político brasileiro de Império para República e o aumento da concorrência entre igrejas que se intensificou a partir da década de 1980. Acreditamos que, a partir desse esforço acadêmico, se viabilizarão, de forma mais consistente, estudos mais específicos sobre o assunto em questão, por parte de economistas brasileiros.

\subsection{Estrutura do trabalho}

A dissertação é composta de seis capítulos. Nesse número, já se incluem este capítulo introdutório (capítulo 1) e as observações finais (capítulo 6). No capítulo 2, é apresentada a metodologia que é essencialmente analítica, ou seja, trata-se de uma análise exploratória, sem o estabelecimento empírico de teste, das principais obras sobre o tema "economia e religião" e ainda, uma análise, também exploratória, do comportamento da Igreja católica brasileira, frente a acontecimentos seculares, principalmente de cunho político e econômico.

No capítulo 3, será feita a revisão de literatura sobre o tema, que trata da influência recíproca entre religião e economia. Através dessa revisão, poderemos notar que o tema é extremamente extenso, fato que abre inúmeros leques de abordagens possíveis. Esse capítulo é composto de três seções. Na primeira, trata-se da relação entre a religião e questões de cunho econômico. A segunda analisa a tese da secularização. A terceira e última define as linhas de pesquisa existentes sobre economia e religião. 
No capítulo 4, analisaremos o representante religioso mais importante do Brasil, a Igreja católica, e sua relação com o secular, ou seja, com acontecimentos não religiosos, de cunho econômico e político, que acabam influenciando as suas decisões. Esse capítulo é dividido em quatro seções. Na primeira, é analisado o impacto sobre a Igreja católica do rompimento do Estado brasileiro com essa instituição, quando da transição do sistema monárquico para o sistema republicano e, ainda, os prováveis motivos que levaram a esse rompimento. Na segunda seção, é analisado o impacto sobre a Igreja católica do aumento da concorrência com as demais instituições religiosas e não religiosas. $\mathrm{Na}$ terceira seção, analisam-se os estímulos ao sacerdócio católico e protestante. Na quarta e última seção, é analisado o impacto de questões de cunho financeiro sobre a Igreja católica. Depois de todos esses esclarecimentos sobre o capítulo 4, acredita-se ser importante mencionar que a análise desse capítulo é uma análise institucional da Igreja católica, ou seja, quando falamos em impacto sobre a Igreja católica, estamos considerando os impactos sobre questões institucionais como: unidade, posição no tocante a outras religiões, influência na sociedade e no Estado, número de adeptos, situação financeira e outros.

No capítulo 5, é feita uma análise da situação atual, da Igreja católica brasileira, ressaltando-se a perda expressiva de fiéis que a mesma vem enfrentando nos últimos anos. Utilizar-se-ão, para isso, os conhecimentos dos capítulos anteriores.

No último capítulo, são ressaltadas as observações finais, as limitações e as recomendações para futuros trabalhos. O objetivo dessas observações finais é servir como fecho do trabalho, sublinhando seus pontos mais importantes. 


\section{METODOLOGIA}

A principal função deste capítulo é explicar o aparato metodológico que será utilizado no decorrer do trabalho, para que se atinja o objetivo nele proposto. A definição da metodologia transformou-se numa das tarefas mais árduas, haja vista a inexistência de uma metodologia pronta, como normalmente acontece em trabalhos da área de economia.

A definição do objeto a ser estudado foi outro desafio, devido à abrangência do tema em questão. Fazer um recorte foi, então, uma das partes mais difíceis, porém necessária, pois sempre que se faz um recorte, tende-se a ganhar em objetividade, aspecto extremamente importante para um trabalho científico. Contudo, esse recorte não deve excluir aspectos relevantes do assunto estudado: aí está uma das maiores dificuldades de delinear o objeto de estudo. Nesse sentido, pode-se dizer que a investigação científica implica fazer escolhas. Mas não se trata de escolhas pessoais e arbitrárias, haja vista que todo trabalho científico está calcado em um aparato teórico e metodológico com os quais é fundamentado o esforço investigativo.

Buscando a objetividade sem perder a relevância, optamos por uma análise histórica dos principais autores que estudaram e estudam o tema "economia e religião". O objetivo dessa revisão bibliográfica é estudar as correntes divergentes e concluir, mesmo que de forma não definitiva, as idéias que norteiam as discussões teóricas sobre o assunto. Essa revisão fazse importante, na medida em que ajuda a delinear o objeto e aí, então, atingir o objetivo deste trabalho de forma mais consistente. Apenas para lembrar, o objetivo que guiará toda esta 
dissertação é fazer uma análise do comportamento da Igreja católica brasileira, como instituição, frente a questões seculares, principalmente de cunho político e econômico.

Para atingir tal objetivo, analisamos os impactos dos principais acontecimentos seculares sobre a Igreja católica brasileira, como instituição. A análise foi elaborada a partir da ótica dos principais estudiosos do tema, e levando em consideração os aspectos, que, segundo Mainwaring (1989), acabam influenciando as instituições religiosas. Esse estudo é essencialmente analítico, ou seja, não foi adotado nenhum modelo empírico de teste. Esperamos, com isso, poder mostrar que aspectos seculares, principalmente de cunho econômico e político, acabam influenciando as decisões institucionais da Igreja católica brasileira. Esperamos, também, poder apontar alguns dos possíveis direcionamentos que têm pautado o comportamento dessa instituição. 


\section{ECONOMIA E RELIGIÃO: UM ASSUNTO ABRANGENTE}

\subsection{A inter-relação entre economia e religião: de John Stuart Mill à atualidade}

Desde Max Weber (1905) e sua obra “A Ética Protestante e o Espírito do Capitalismo”, os economistas iniciaram uma ampla discussão sobre a inter-relação entre economia e religião. A importância que esse tema tem apresentado pode ser observada através da ação da universidade de Harvard, que agrega hoje um grupo específico de cientistas estudando o tema. ${ }^{1}$ Outros autores importantes na história da economia, da sociologia e da teologia, anteriores e posteriores a Max Weber, também se debruçaram sobre o tema, conforme veremos neste capítulo.

Para atingir o objetivo deste capítulo, foi feita uma revisão, em ordem cronológica, das principais obras sobre o tema. O objetivo central dessa abordagem histórica é apresentar a diretriz da evolução do pensamento sobre o tema em questão e tentar explicar por que algumas idéias se sobressaíram, em detrimento de outras. É importante ressaltar, ainda, que alguns pensadores, principalmente os anteriores a Max Weber, abordavam o tema "economia e religião" de forma secundária. Por isso, muitas vezes, a análise do pensamento desses autores pode parecer reduzida. Entretanto, o que de fato acontece é que eles não tinham uma opinião amadurecida sobre o assunto, ou não tinham uma preocupação mais intensa sobre o tema.

\footnotetext{
${ }^{1}$ Para maiores detalhes e diversas publicações sobre o assunto ver http:/www.wcfia.harvard.edu/programs/prpes/
} 
John Stuart Mill ressalta o fato de a Igreja estar associada à educação primária e do poder de influência, que isso lhe dá, sobre os desejos involuntários, como ele próprio diz. Psicólogos dão suporte a essa tese, na medida que definem o ser humano como um misto entre genética e convívio social. Stuart Mill afirma ainda, que a Igreja tem influenciado a opinião pública e, o poder de julgamento desta, tem direcionado as ações de grande parte da população (Birnbaum \& Gertrud, 1969, p.96-100).

Karl Marx discute se a Igreja influencia as atitudes humanas, ou se são as atitudes humanas que influenciam a Igreja, constituindo-a e conclui que essa discussão sobre o assunto não é definitiva. Mas isso não é o mais importante. O que realmente importa, e deve ser amplamente discutido, é o papel de amortecedor social que ela desempenha. Nessa direção, Marx relata uma série de exemplos, nos quais tenta mensurar a reação humana, em situações nas quais a religião está inserida no contexto e onde não está, chegando sempre a desdobramentos diferentes, fato que demonstra a sua preocupação com a causalidade existente entre economia e religião. Marx preocupa-se, ainda, em deixar claro que ele concorda com a idéia de que o Protestantismo é melhor para o crescimento econômico do que o Catolicismo (Birnbaum \& Gertrud, 1969, p.94-95).

Friedrich Engels compara o Socialismo e o Cristianismo e ressalta que ambos surgiram com o objetivo de ajudar os oprimidos. Menciona, ainda, que o Cristianismo, que começou como religião da minoria, se tornou a religião da maioria, mas, na contrapartida, estimulou os oprimidos a não se rebelarem e a esperarem pelo paraíso da eternidade. E o Socialismo aparece como solução, na Terra, para a classe oprimida. Portanto, Engels ressalta a importância da Igreja como ferramenta de influência na sociedade (Birnbaum \& Gertrud, 1969, p. 213).

Ernst Troeltsch conclui que há uma relação muito próxima entre religião e economia, no sentido de uma influência mútua, fato que, segundo ele, tem sido pouco estudado. Ele endossa a idéia de Weber de que a Igreja influencia a economia, e reforça esta tese com diversos exemplos históricos, tais como Índia e China (Birnbaum \& Gertrud, 1969, p.198-200). 
Max Weber deixa claro que acredita que o Puritanismo ${ }^{2}$ estimulou o desenvolvimento do capitalismo de forma mais acentuada do que o Catolicismo, e deixa isso explícito já no início da sua obra "A Ética Protestante e o Espírito do Capitalismo", conforme podemos observar a seguir.

"Por outro lado, impõe-se o fato de os protestantes (especialmente em alguns de seus ramos que serão discutidos mais adiante), tanto como classe dirigente, quanto como classe dirigida, seja como maioria, seja como minoria, terem demonstrado tendência específica para o racionalismo econômico, que não pode ser observada entre os católicos em qualquer uma dessas situações. A razão dessas diferentes atitudes deve, portanto, ser procurada no caráter intrínseco permanente de suas crenças religiosas, e não apenas em suas temporárias situações externas na história e na política” (Weber, 1967, p.23).

Através dessa passagem do livro de Weber, podemos perceber que ele defende que a religião influencia diretamente a forma de ser das pessoas e, com isso, influencia o capitalismo.

Apesar de explicitar essa crença já no início da sua obra, ele também discute como a riqueza econômica dos protestantes poderia ser explicada por fatores históricos, como, por exemplo, por herança. Mas ele lembra que, apesar de isso ser possível, haveria de se explicar o porquê de esses antepassados terem se convertido para o protestantismo. Ele mesmo conclui que se trata de uma discussão mais ampla, que ele não abordará em seu livro, mas lembra que essa discussão não diminui o fato de que há uma inter-relação histórica entre desenvolvimento econômico e Protestantismo. Essa discussão mais ampla, hoje em dia, é objeto de estudo de Ekelund, conforme veremos mais àfrente.

Weber entende que a Reforma Protestante não aconteceu com o objetivo de influenciar o capitalismo, ou o seu surgimento. Lembra, também, que afirmar que o "espírito capitalista" só se

\footnotetext{
${ }^{2}$ O Puritanismo é uma seita de presbiterianos mais rigorosa na aplicação de princípios morais, e que pretendia interpretar melhor do que ninguém o sentido literal das escrituras.
} 
estabeleceu devido à Reforma Protestante é uma tolice, mas que o Protestantismo influenciou positivamente o desenvolvimento do capitalismo (Weber, 1967, p.61-62).

Sua obra discute algumas das várias vertentes de Igrejas protestantes, tais como: a luterana, a calvinista, a anglicana e outras, citando sempre alguns exemplos de influências diversas que elas exercem sobre o "espírito do capitalismo", mencionando inclusive que, apesar de algumas influenciarem mais intensamente esse espírito do que outras, todas acabam influenciando positivamente o desenvolvimento do "espírito do capitalismo", quando comparadas ao Catolicismo.

Weber menciona uma série de aspectos defendidos pelo Protestantismo, que não o são pelo Catolicismo, e que acabaram influenciando o "espírito do capitalismo", tais como: o desejo infinito de melhorar financeiramente, a poupança, a vocação como estímulo para a especialização da mão-de-obra, a abolição da confissão como estímulo à ética e vários outros aspectos, citados a todo momento em sua obra.

A afirmação acima pode ser constatada na frase abaixo transcrita:

"Combinando essa restrição do consumo com essa liberação da procura de riqueza, é óbvio o resultado que daí decorre: a acumulação capitalista através da compulsão ascética à poupança. As restrições impostas ao uso da riqueza adquirida só poderiam levar a seu uso produtivo como investimento de capital" (Weber, 1967, p.124).

Max Weber ressalta, ainda, através da frase transcrita a seguir, que a religião influencia a economia, mas que o contrário também é verdadeiro, e estimula estudos futuros sobre o poder de influência de aspectos econômicos na religião (Weber, 1967, p.132).

"Seria, todavia, necessário investigar mais adiante, a maneira pela qual a ascese protestante foi, por sua vez, influenciada em seu desenvolvimento e caráter pela totalidade das condições sociais, especialmente pelas econômicas (Weber, 1967, p.132).” 
Werner Sombart, através de sua obra "The Jews and Modern Capitalism”, embasada nas idéias de Max Weber, aponta que a religião judaica é um dos principais motivos, quando o assunto é explicar o ótimo desempenho econômico do povo judeu. Ele acredita que o Judaísmo tem um poder de influência sobre o "espírito capitalista" ainda maior que o Protestantismo (Sombart, 1951, p.191-192).

"Eu acho que o Judaísmo tem intrínseco a ele as mesmas doutrinas que norteiam o Capitalismo. Eu vejo o mesmo espírito em ambos" (Sombart, 1951, p.205).

Sombart ressalta, ainda, a questão da homogeneidade do povo judeu em torno de um único objetivo, o sucesso aqui na Terra, como outro aspecto decisivo para a determinação do sucesso econômico desse povo. Ele passa grande parte do seu livro analisando também as diferenças entre o Judaísmo e o Catolicismo, com o objetivo de mostrar que o primeiro é mais compatível com o sucesso pessoal, dentro das regras do sistema capitalista.

Werner Sombart deixa bem clara sua opinião de que o Judaísmo tem efeitos positivos para o desenvolvimento do capitalismo, ao ressaltar que, segundo essa religião, Deus beneficia quem trabalha e luta aqui na Terra e ressalta, ainda, que a pessoa que luta aqui na Terra também será beneficiada no Céu (Sombart, 1951, p.215).

A idéia de Werner Sombart de que o motivo do sucesso econômico do povo judeu está na sua religião pode ser observada nas duas frases que seguem:

"Eu já mencionei que o estudo de Max Weber sobre a importância do Puritanismo para o sistema capitalista foi o fato que me levou a considerar a importância do Judaísmo para o capitalismo. Eu acredito que as idéias predominantes no Puritanismo, que foram tão poderosas para o desenvolvimento do capitalismo são ainda melhor apresentadas no Judaísmo, e obviamente muito anteriores as idéias puritanas" (Sombart, 1951, p.248). 
"Estes quatro elementos, intelectualidade, teologia, energia e mobilidade, são os elementos que compõem o caráter judeu. Eu acredito que todas as qualidades dos judeus podem ser descritas por estes elementos, que são de extrema importância para a vida econômica" (Sombart, 1951, p.268).

Sua principal obra, aqui analisada, deixa clara sua discordância das idéias de Weber, quando o assunto é a influência do Puritanismo no desenvolvimento do "espírito do capitalismo". Para Sombart, o Judaísmo possuía idéias mais adaptadas ao "espírito do capitalismo", além de serem muito anteriores às idéias protestantes. Ele chega a especular, com a hipótese de que as idéias do Judaísmo teriam influenciado a formação das idéias protestantes, citando uma série de evidências para isso (Sombart, 1951, p.248-251).

Amintore Fanfani, um historiador econômico e ex-ministro italiano, também se debruça sobre o tema "economia e religião". Ele defende as idéias de Max Weber, mas com algumas ressalvas; por exemplo: ele não acredita que o Protestantismo tenha estimulado o surgimento do capitalismo, haja vista que a Reforma Protestante ocorreu depois do surgimento do capitalismo. Mas ele conclui que o Protestantismo estimulou o desenvolvimento desse sistema, facilitando o sucesso deste, através da retirada de obstáculos de natureza espiritual ao capitalismo. Entretanto, ele lembra que o Protestantismo não é o único responsável por tal sucesso, já que existem outros aspectos, de igual importância, como a situação geográfica, política e tecnológica (Fanfani, 1953, p.253-279).

Quando a questão é como seria possível haver "espírito capitalista" em países católicos, Fanfani ressalta que a debilitação da fé é a circunstância que explica a consolidação do "espírito capitalista" em países católicos e, em um certo sentido, o oposto também ocorre, ou seja, a consolidação do "espírito capitalista", causado pela concorrência entre protestantes e católicos, acaba acarretando uma diminuição da fé católica (Fanfani, 1953, p.241-242). 
Fanfani também acredita que a doutrina católica atrapalha o pleno desenvolvimento do capitalismo e deixa isso claro através das seguintes passagens:

"Se eu, empresário, tenho que abastecer uma fábrica com matérias primas, tentarei adquiri-las segundo o critério do custo econômico mínimo. No entanto, como sou católico, deverei comprovar que este critério não está em oposição aos objetivos católicos, que são superiores aos econômicos. Por exemplo, objetivo de natureza social, se existe oposição a este objetivo, não posso vacilar e devo preferir o meio economicamente mais custoso, no entanto, mais racional socialmente falando. Depois de comprovado que minha política está me levando a Deus poderei considerar que estou administrando licitamente, segundo os preceitos católicos, a minha atividade econômica" (Fanfani, 1953, p. 178).

"Sem dúvida, repetiremos uma vez mais, que no fundo a razão verdadeira e última da oposição entre a ética católica e a ética capitalista se encontra na diferente forma de ligar as ações humanas (e no caso específico, as ações econômicas) com Deus. Já dissemos, que o católico mede a legalidade de todo ato de acordo com os critérios cristãos, enquanto o capitalismo não duvida da hombridade de todo ato que esteja de acordo com as exigências do que ele considera razão da existência humana" (Fanfani, 1953, p.195).

Robertson fez um ótimo trabalho de sistematização das idéias contrárias à tese de Weber, no qual criticou os seguintes aspectos: 1) a doutrina da vocação. Ela estimula o desenvolvimento do capitalismo através do incentivo à especialização e, como consequência, o aumento da produtividade e, com isso, todas as vantagens econômicas que disso advêm. Porém, este incentivo não é um privilégio do Protestantismo, pelo contrário. Para o autor, o incentivo à busca da vocação individual, independente da profissão, foi construído pelos católicos, através dos escritos de autores jesuítas, que associavam, assim como os protestantes, a idéia de que qualquer tipo de trabalho e o amor a Deus não são realidades desconexas; 2) a questão do surgimento do capitalismo. Para Robertson, esse sistema surge com os mercadores italianos, ou seja, muito 
antes da Reforma Protestante e, portanto, não há nenhuma relação entre os dois. No entanto, deve-se ressaltar que Robertson está falando do capitalismo tradicional', enquanto Weber faz sua análise com base no capitalismo moderno ${ }^{4}$; 3 ) o Puritanismo não implica necessariamente no capitalismo e o Catolicismo não implica necessariamente em atraso econômico. Para Robertson, aspectos geográficos definiam muito melhor o nível de desenvolvimento capitalista de países como Inglaterra, Holanda e Bélgica; 4) o Renascimento e o Estado a ele correspondente, segundo Robertson, estimularam o capitalismo, e não a doutrina protestante; 5) a moral puritana seria muito mais hostil ao capitalismo que a moral católica, pois, para Robertson, Lutero e Calvino eram muito mais críticos de aspectos como taxa de juros do que escritores católicos (Robertson, 1959, p.20).

Kurt Samuelsson faz uma revisão bibliográfica completa das idéias sobre economia e religião, principalmente da obra de Max Weber, e se posiciona diametralmente contra, de forma ainda mais radical que Robertson. Ele acredita que não haja uma relação de influência, entre a religião e o capitalismo, tão relevante quanto Weber descreve.

Samuelsson defende a idéia de Sombart, de que o "espírito capitalista" já existia nos mercadores italianos do período mercantilista, que eram católicos. Portanto, para Samuelsson, não foi o Protestantismo que estimulou o surgimento do espírito do capitalismo (Samuelsson, 1961, p.67).

Samuelsson desconsidera a diferença entre o capitalismo tradicional e o capitalismo moderno; sem levar em conta essa diferença, ele acaba estruturando sua crítica a Weber, descrita no parágrafo anterior. Mesmo assim, Samuelsson não consegue derrubar a tese de Weber de que

\footnotetext{
${ }^{3}$ É o tipo de capitalismo mercantilista, no qual o capitalista não se preocupava em não ostentar, investir em sua empresa, a regra geral era a do saque às colônias. Os empresários eram especuladores em larga escala, colonizadores, ou seja, orientados pela apropriação através da força.

${ }^{4}$ Esse tipo de capitalismo privilegia a frugalidade, a preocupação com o investimento para o crescimento das empresas. Baseia-se na expectativa de lucro através da utilização das oportunidades de troca, isto é, nas possibilidades pacíficas de lucro. Está calcado na utilização planejada de recursos materiais e pessoais.
} 
o Protestantismo estimulou e liberou a mente das pessoas para o surgimento desse espírito, enquanto o Catolicismo o censurava.

Weber, afirma que o zelo com os bens materiais e a poupança são atitudes estimuladas pelo Protestantismo, que o Catolicismo acabou não estimulando. Mas, segundo Samuelsson, não são essas as qualidades que determinaram o surgimento das grandes fortunas e, portanto, do capitalismo atual, pois, segundo seu raciocínio, ninguém conseguiria poupar cem, duzentos milhões de dólares em uma vida. Entretanto, o autor desconsidera que a poupança é uma condição indispensável para o crescimento econômico de longo prazo ${ }^{5}$ (Samuelsson, 1961, p.7987).

Samuelsson ressalta, através de exemplos como a Bélgica católica e a Holanda calvinista e católica ao mesmo tempo, a impossibilidade de dizer que o Protestantismo implica maior desenvolvimento econômico do que o Catolicismo, haja vista que, na Holanda, o Protestantismo só se estabeleceu depois de o capitalismo já estar consolidado e, mesmo assim, só para uma parte da população, pois a outra continuou sendo católica e totalmente inserida no sistema capitalista. O desenvolvimento suíço e outras justificativas, que não as religiosas, para o desenvolvimento e a retração das diversas áreas da Alemanha e dos E.U.A. também são usados como exemplos da fragilidade da tese de Weber (Samuelsson, 1961, p.103-121).

Mas o próprio Samuelsson ressalta que esses exemplos não são suficientes para dizer, de forma definitiva, que o Protestantismo não serviu de forma alguma como um instrumento positivo para o desenvolvimento do capitalismo. Samuelsson também não consegue provar que o Catolicismo tenha sido uma ferramenta tão importante quanto o Protestantismo, para esse desenvolvimento, mas apresenta uma série de brechas na teoria de Weber; critica, inclusive, aspectos técnicos dessa tese, como a amplitude do tema e a má definição do objeto, e termina

\footnotetext{
${ }^{5}$ A veracidade da afirmação de que o crescimento econômico de longo prazo é dependente do nível de poupança de uma nação pode ser atestada em (Mankiw, 2001, p.539).
} 
sua obra ressaltando que não acredita numa relação tão direta de causalidade entre religião e economia, como Weber acreditava (Samuelsson, 1961, p.148-154).

O historiador e economista Luís Corrêa Lima faz uma ampla revisão bibliográfica sobre economia e religião. Expande seu período de estudo e define o mercantilismo como a data do surgimento do capitalismo, e não a Revolução Industrial, como Weber faz. Isso porque ele acredita que as raízes do capitalismo se encontram nesse período. A partir desse novo contexto, ele passa a criticar as idéias de Weber e acaba concluindo que a escolástica e o Catolicismo tiveram papel determinante e positivo na instituição do que ele chama de capitalismo comercial (Lima, 2001, p.243-285).

Michel Falise, um autor mais atual, conclui que o Cristianismo pode influenciar o capitalismo. Essa conclusão fica evidente através do excerto que transcrevemos a seguir. Entretanto, ele não aprofunda sua conclusão e também não se envolve na discussão Catolicismo x Protestantismo.

"Ficou patente que a liberdade e o querer dos homens podem imprimir direção à economia e que essa direção pode receber luz e força do olhar ético. Dentro dessa perspectiva, cada qual está convidado a discernir quais os graus de liberdade pessoal aqui e agora, a tomar consciência dos interesses associados, a explicitar os valores que vão ser guias de suas opções, a tornar as preferências e os valores solidários com algum significado de homem e sua dignidade. Viver a prática econômica - quinhão nosso de cada dia - pode transformar-se em viver a ética econômica. Para o cristão, cuja fé precisa dar sentido e força à vida como um todo, trata-se de viver a prática cristã”, (Falise, 1991, p.175).

Economista contemporâneo, da Universidade de Michigan, Daniel Fusfeld, também acredita que a doutrina católica é antagônica à doutrina capitalista e que essa oposição acaba 
atrapalhando o desenvolvimento pleno desse sistema econômico. Ele ressalta, ainda, que foi tal antagonismo que acabou estimulando a Reforma Protestante.

"Esse dilema moral - o conflito entre a salvação e o sucesso - foi um fator importante para preparar o terreno para a Reforma Protestante. Era difícil a um mercador urbano acreditar que o modo de vida baseado nos negócios fosse menos correto do que outros. Era complicado entender que a concorrência necessária para se sobreviver fosse antagônica à moral, que a procura pessoal pelo lucro, fundamental para o ganha - pão dos negociantes, não fosse aprovada por Deus. Dúvidas foram, então, levantadas. Estariam certos os teólogos em sua pregação sobre o modo de conduta que levava à salvação? Afinal de contas, eles eram apenas seres humanos, como quaisquer outros, e sujeitos aos erros humanos. O que a Bíblia dizia sobre esses assuntos? Essas questões levaram àheresia protestante - pôs-se em dúvida a infalibilidade da Igreja e manifestou-se o desejo de consultar diretamente a Bíblia, repositório das leis de Deus, sem a intermediação de padres" (Fusfeld, 2001, p.15).

Até Charbonneau, um teólogo profundamente católico, faz a seguinte afirmação sobre o assunto.

"A revolução protestante oferecia, portanto, um condicionamento ideológico e religioso ideal ao capitalismo nascente. A tese de Weber é hoje admitida no que tem de essencial e, ainda que seja preciso corrigir algumas de suas contestáveis conclusões, podemos dizer que se impõe em seu conjunto" (Charbonneau, 1967, p.148).

O trabalho "Ópio do povo? O impacto econômico da religião" constitui, em grande parte, uma tentativa de teste estatístico das idéias de Weber, através dos dados do Relatório dos Valores Mundiais ${ }^{6}$. Os autores desse trabalho tentam medir o efeito da religião, na média e de

\footnotetext{
${ }^{6}$ Esse relatório é elaborado pela Universidade de Michigan e originalmente tem o seguinte nome "The World Values Survey ”. É feito em 66 países e apresenta dados para o período de 1981 a 1997.
} 
forma desagrupada, sobre quatro variáveis econômicas: cooperação, governo, regras legais e economia de mercado (Guiso et al., 2002, p.2-4).

Os autores pautam o trabalho nas idéias de Weber. Na verdade, o principal objetivo deles é testar se a religião desempenha um papel importante na determinação do crescimento econômico de cada país. Apesar de esse trabalho apresentar indícios de que tal relação existe, os autores concluem que o assunto ainda está em aberto, haja vista que a causalidade não pôde ser comprovada e a possibilidade de se tratar de uma mera coincidência sempre existe.

Um dos motivos pelos quais eles acreditam que a religião seja importante para o desenvolvimento econômico é que as pessoas religiosas confiam mais umas nas outras, confiam mais no governo e têm menos incentivos para quebrar as leis, fatores que fortalecem as instituições (Guiso et al., 2002, p.5).

Uma das observações desse trabalho é, no mínimo, curiosa: o fato de que países permeados pela cultura católica, contrária à usura, tendem a dar menos proteção para o seu sistema de crédito. Os autores não concluem, mas acredito que, com isso, queiram sugerir uma explicação para o menor desenvolvimento desses sistemas nesses países (Guiso et al., 2002, p.12).

Os resultados mostraram que o efeito da religião sobre as pessoas, quando o assunto é cooperação, governo, regras legais e economia de mercado, na média, é positivo para o desenvolvimento de atitudes que conduzam ao crescimento econômico. A principal exceção é a questão da igualdade, quando comparada à individualidade. Os católicos são mais a favor da igualdade do que os protestantes. Quando o assunto é governo, a exceção são os judeus, que, na sua maioria, desconfiam dos governos, principalmente em países predominantemente católicos, possivelmente devido à discriminação que sofreram no passado (Guiso et al., 2002, p.30-31).

Os resultados do trabalho em questão sugerem que existe algo na cultura dos países predominantemente católicos que impactou negativamente sobre a sua habilidade de crescimento. 
Contudo, esses aspectos parecem não estar presentes nesses países, atualmente. Uma possível explicação para isso é que tais aspectos não sejam específicos do Catolicismo, mas digam respeito a outros traços da cultura desses povos. Outra explicação possível é que esses aspectos tenham sido parte do Catolicismo do passado, mas perderam-se após a introdução do Concílio do Vaticano II $^{7}$. As evidências encontradas nesse trabalho apontam para a segunda hipótese; entretanto, não são suficientes para se chegar a uma conclusão definitiva. A única conclusão possível sobre o assunto, no momento, é que o Catolicismo não é mais um obstáculo ao desenvolvimento econômico (Guiso et al., 2002, p.31).

Robert Woodberry faz parte da linha de intelectuais da atualidade que estudam a relação entre economia e religião, e partem em sua análise das mesmas premissas que pautaram as idéias de Max Weber. Em seu ensaio "Democratização nas Sociedades Pós-Coloniais: As influências de Longo Prazo da Religião e dos Governos Coloniais", ele analisa a relação do Protestantismo e do colonialismo inglês com o sistema político que se estabeleceu nos países colonizados, após o término do período colonial.

Woodberry conclui que as colônias inglesas, quando comparadas às demais colônias européias, apresentam um nível educacional muito maior, que acabou resultando em maior conscientização das diversas classes sociais e, consequentemente, em maior nível de democratização dessas sociedades. Isso tudo só foi possível, segundo Woodberry, porque havia concorrência entre as missões, normalmente protestantes, e

não havia relação de dependência financeira dessas missões com o Estado colonial inglês (Woodberry, 2002, p.30-33).

Rachel McCleary analisa a relação entre salvação e incentivos econômicos, em cada uma das quatro maiores religiões, em número de fiéis, no mundo (Cristianismo, Islamismo, Hinduismo

\footnotetext{
${ }^{7}$ O Concílio do Vaticano II consistiu em um novo direcionamento dado à doutrina da Igreja católica no ano de 1962, no papado de Paulo VI.
} 
e Budismo), partindo da tese de Weber, segundo a qual religião e economia mantêm uma relação de influência.

Após fazer uma análise descritiva da doutrina da salvação de cada uma das quatro religiões, ela chega a duas conclusões, como: 1) as quatro religiões acreditam que a riqueza é algo positivo e a pobreza, negativo e, por isso todas elas estimulam, em sua doutrina, o crescimento econômico; 2) religiões que enfatizam mais a crença no inferno do que no céu (cristãs e islâmicas) acabam incentivando aspectos como trabalho, poupança e empréstimos, que estimulam o crescimento econômico, enquanto religiões como o Hinduísmo e o Budismo enfatizam a crença no céu e a distribuição de renda sob a forma de doação, como meio de alcançá-lo, atitude que, segundo a autora, contribui menos para o crescimento econômico (McCleary, 2002, p.33-42).

Quase todos os autores aqui analisados convergem para a aceitação da idéia de que a religião exerce influência sobre o comportamento econômico das pessoas e que tal fato é importante para a economia como um todo. O que não é consenso é sobre a forma e a intensidade da influência positiva do Protestantismo sobre o crescimento econômico.

Essa influência da religião sobre a economia apresenta-se de diversas formas; uma delas é observável na análise da inserção das religiões nas sociedades. Quando ela ocorreu, as religiões não eram unanimidade e sempre foram um meio de classes sociais imporem suas idéias sobre as demais classes. Como exemplo, pode-se citar a associação do poder da monarquia ao poder divino, feita pela Igreja católica, face à recompensa financeira que recebia, conforme pode ser observado nas evidências históricas, apresentadas por Chiavenato, em sua obra aqui analisada. Pode-se citar, também, o poder de evangelização exercido pela Igreja católica sobre os índios, através das missões.

Dentre os primeiros autores que se preocuparam com a influência da religião sobre a economia, alguns como Ernst Troeltsch, Karl Marx e Max Weber, foram mais além, e ressaltaram uma influência mútua entre religião e economia. No entanto, empiricamente, os 
economistas têm concentrado todos os seus esforços em analisar o poder de influência da religião sobre a economia, em detrimento do oposto, mesmo sabendo que as duas realidades estão correlacionadas. Deve-se ressaltar esse fato, porque a pesquisa feita não encontrou sequer um trabalho analisando o poder de influência da economia sobre a religião.

Os primeiros estudiosos sobre o tema, Mill, Marx, Engels, Troeltsch e Marshall, não tinham como preocupação central, em seus trabalhos, a relação entre economia e religião. Portanto, limitavam-se a concluir que havia uma relação de interferência da religião sobre a economia.

Dos críticos das idéias de Weber, como Sombart, Fanfani, Samuelsson, Robertson e, mais recentemente Lima, pode-se dizer que algumas colocações têm fundamento e outras não, conforme pode-se observar na análise de cada um destes autores. No entanto a idéia de que o Protestantismo liberou a mente das pessoas para pensar de forma capitalista, quando do surgimento do capitalismo industrial, coisa que o Catolicismo não fez, não consegue ser derrubada pelas argumentações de nenhum deles.

Os autores contemporâneos que estudam o assunto, principalmente Guiso, Woodberry e McCleary, estão encontrando resultados empíricos que dão suporte às idéias de Weber.

Após analisar os argumentos dos críticos e dos simpatizantes de Weber, quanto ao assunto Capitalismo x Protestantismo, podemos concluir que, apesar das eventuais falhas na obra de Weber, ela não consegue ser totalmente contestada e a idéia central de que o capitalismo moderno foi impulsionado pelo Protestantismo, muito mais do que pelo Catolicismo, se impõe.

\subsubsection{Prováveis motivos que incentivaram a Reforma Protestante}


Na literatura, existem três justificativas plausíveis para a Reforma Protestante. Não se trata de justificativas excludentes, ou seja, é possível que todas façam parte da explicação dos motivos que levaram à Reforma Protestante.

Acredita-se que entender esses motivos é de suma importância, para que se compreenda, de forma mais consistente, a obra de Max Weber aqui analisada, sendo que todas as justificativas indicam que a Igreja católica não apresentava uma sinergia com o sistema econômico que surgia, o capitalismo.

A primeira justificativa é a dos reformistas protestantes, que afirmavam que a Igreja católica perdera influência porque se tornara ética e moralmente corrupta. A segunda, de historiadores, que afirmavam que a Reforma Protestante ocorreu porque, em alguns lugares, a Igreja católica se posicionara a favor de grupos sociais que haviam perdido poder político e econômico para outros grupos sociais. Finalmente, os economistas aceitam mais a hipótese de que religiões que são monopolistas ${ }^{8}$ tendem a ser ineficientes e a praticar "rent-seeking", e, com isso, abrem espaço para a entrada de competidores mais eficientes.

As duas primeiras justificativas, referidas no parágrafo anterior, são de fácil compreensão; no entanto, a terceira é mais complexa. Para explicá-la, utilizaremos a obra "Uma Análise Econômica da Reforma Protestante", de Ekelund, um autor contemporâneo, que estuda o tema em questão utilizando o ferramental microeconômico.

Com o objetivo de explicar e ampliar a conclusão dos economistas, Ekelund afirma que religiões monopolistas, podem se comportar como empresas monopolistas, e abusar do preço cobrado por seus serviços, com isso, arriscam-se a perder influência de duas formas: a) seus fiéis

\footnotetext{
${ }^{8}$ Religiões monopolistas são religiões que não enfrentam competição, assim como o catolicismo era na Europa medieval.

${ }^{9}$ Política adotada por agentes econômicos, que tem como objetivo abocanhar uma parte da renda da sociedade sem ter contribuído para sua formação.
} 
podem procurar outra religião que preste um serviço similar a um preço ${ }^{10}$ menor, ou b) o governo que está sendo excessivamente taxado pode procurar outro parceiro nessa área. Esta segunda hipótese é ressaltada por Ekelund como uma possível justificativa para a Reforma Protestante, e, obviamente, considera a existência de uma religião estatal (Ekelund et al., 2002, p.647-648).

Ekelund ressalta ainda que a Igreja católica medieval praticava um sistema sofisticado de discriminação de $\operatorname{preços}^{11}$, sempre com o objetivo de extrair, ao máximo, o excedente do consumidor $^{12}$. Segundo o autor, isso acabou estimulando a entrada de religiões rivais, oferecendo produtos modificados. Ele ressalta que, em sociedades mais atrasadas, semi-feudais, a associação entre o Estado e a Igreja católica era mais comum e impedia a entrada de igrejas rivais; já em sociedades mais avançadas e caracterizadas pelo espírito empreendedor, houve um estímulo à busca de igrejas rivais à Igreja católica, que permitissem a maximização do excedente do consumidor ${ }^{13}$ pelo consumidor (Ekelund et al., 2002, p.648-649).

A análise de Ekelund é dividida em duas vertentes, a da demanda e a da oferta. $\mathrm{Na}$ da demanda, ele afirma que medidas, como a cobrança escandalosa de indulgências, mudaram o gosto das pessoas, deslocando a curva de demanda pelo Protestantismo para a direita ${ }^{14}$. Diz também que iniciativas como a excomunhão, as Cruzadas e as Inquisições, foram usadas com o objetivo de reduzir a concorrência à Igreja católica. Outro fator que viabilizou a Reforma Protestante foi o comportamento da Igreja católica de monopólio discriminador de preços, fato que extraía, ao máximo, o excedente do consumidor que apresentava uma curva de demanda por redenção inelástica (Ekelund et al., 2002, p.649-651).

\footnotetext{
${ }^{10}$ Quando se fala em preço do serviço religioso, está se falando em dízimo, cobrança de indulgências e, no caso do preço pago pelo Estado, está se falando da contribuição que este dava para o pagamento dos salários dos padres e para a manutenção da igreja.

${ }^{11}$ A discriminação de preços consiste numa prática comercial de vender o mesmo bem, a diferentes compradores, por preços distintos.

${ }^{12}$ Excedente do consumidor é a quantia que o comprador está disposto a pagar por um bem, menos a quantia que ele paga de fato.

${ }^{13}$ A maximização do excedente do consumidor, pelo próprio, consiste em abocanhar os benefícios do aumento da concorrência pelo consumidor.

${ }^{14} \mathrm{O}$ deslocamento da curva de demanda à direita, consiste na representação gráfica do aumento da demanda.
} 
$\mathrm{Na}$ vertente da oferta, Ekelund afirma que, em lugares nos quais o feudalismo e a concentração de renda eram fortes e não havia grande mobilidade social, possibilitava-se à Igreja católica associar-se às elites e manter-se como uma instituição monopolista que praticava a discriminação de preços, fato que acabava reduzindo a oferta de outras religiões. Já em sociedades nas quais havia uma mobilidade social mais intensa, imperava a busca do lucro e havia uma baixa concentração de renda, a associação entre a Igreja católica e a classe dominante, que viabilizava o monopólio da religião, ficava mais difícil de ser implantada na prática, fato que acabou gerando a entrada de novas religiões, impedindo a Igreja católica de praticar a discriminação de preços (Ekelund et al., 2002, p.652).

Fora da análise de oferta e demanda, Ekelund afirma que a discriminação de preços era viabilizada pelo processo da confissão. Através dele, a instituição conhecia os desejos das pessoas e descobria as suas disponibilidades financeiras; assim, determinava um valor individual para o pagamento de indulgências e de penitências. No entanto, para que tal processo se viabilizasse, era necessário que a Igreja católica detivesse o monopólio da religião, que não houvesse bens substitutos, isto é, religiões alternativas e que houvesse variação da elasticidade da demanda ${ }^{15}$ das curva dos indivíduos. As pessoas mais ricas, das sociedades mais atrasadas, precisavam da Igreja para se manter no poder. Portanto, não havia bens substitutos para elas. Com isso, pode-se dizer que a elasticidade da sua curva de demanda era mais baixa ${ }^{16}$. Enquanto, as pessoas mais pobres tinham suas religiões populares como bens substitutos e, portanto, tinham curvas de demanda mais elásticas $^{17}$ (Ekelund et al., 2002, p.653).

Por último, Ekelund afirma que, com o Protestantismo, o fiel ficou autorizado a buscar sua salvação diretamente com Deus, sem intermédio do padre, fato que impediu essa religião de cobrar por seus serviços com a mesma eficiência da Igreja católica. Como a classe mais alta era a

\footnotetext{
${ }^{15}$ A elasticidade da demanda é a medida da intensidade da resposta da quantidade demandada a alterações no preço do bem.

${ }^{16}$ Uma curva de demanda com elasticidade mais baixa, também pode ser chamada de inelástica. Essa definição consiste no fato de que a quantidade responde muito pouco a grandes variações no preço.
} 
que mais via seu excedente ser expurgado pela Igreja católica, esta migrou para o Protestantismo. Para concluir, Ekelund afirma que o expurgo do seu excedente econômico determinou a ida das classes mais abastadas para o Protestantismo, e não o escândalo que a cobrança das indulgências representava na época, apesar de ser vista com péssimos olhos (Ekelund et al., 2002, p.657$658)$.

É importante ressaltar que Ekelund desconsidera aspectos culturais e subjetivos, em sua análise. No entanto, nos fundadores do protestantismo, a crítica moral ao catolicismo era muito forte.

Há que se entender também, porque a migração das pessoas, continuam em direção ao protestantismo, sendo que talvez o preço cobrado pelos serviços religiosos das Igrejas protestantes seja maior do que o da Igreja católica. Tentar-se-á discutir esse assunto no capítulo 5.

\subsection{A tese da secularização e o desenvolvimento econômico}

Pode-se, a partir de agora, abordar os conceitos de desenvolvimento econômico e a influência da religião sobre a sociedade, fazendo uma análise mais detalhada do assunto.

Ao se falar de desenvolvimento econômico, ficam implícitas as idéias de crescimento, progresso, evolução, maturação/maturidade, modernização/modernidade, ou seja, conceitos incutidos em nosso modo de pensar ocidental moderno, ou melhor, capitalista pós - industrial (Ribeiro, 2001, p.29). Para se ter uma definição mais técnica do que é desenvolvimento econômico, podemos citar a que segue.

\footnotetext{
${ }^{17}$ Uma curva de demanda elástica é uma curva que pequenas variações no preço acabam gerando grandes variações na quantidade.
} 
"Crescimento econômico (aumento do Produto Nacional Bruto per capita) acompanhado pela melhoria do padrão de vida da população e por alterações fundamentais na estrutura de sua economia" (Sandroni, 2001, p.169).

É importante esclarecer ainda que, quando se fala de influência da religião sobre a sociedade, se fala da influência da doutrina de uma religião sobre o modo de pensar e de agir das pessoas e, consequentemente, sobre a forma de organização das instituições capitalistas.

As definições contidas nos parágrafos anteriores valem para todo o conteúdo deste trabalho.

Inicia-se essa análise pelo Brasil. Um dos precursores do nosso desenvolvimento econômico industrial foi Barão de Mauá que, ao que parece, recebeu influência da sua formação religiosa, conforme ressalta Alberto de Faria, escritor da sua biografia.

"Num país em que a religião católica era a religião do Estado e a crença do povo, raras vezes lhe acode a idéia de Deus que vem associada a religião oficial e aí mesmo se sente que há mais hábito literário que uma manifestação de fé. Figura forçada de todas as grandes obras de caridade e de ensino, doutrinando a seus sócios que a Casa Mauá deve em todas as subscrições, figurar nos primeiros lugares sem requerer muito do fundo e do mérito das solicitações, é um caso curioso que Mauá raramente aparecesse nas várias associações que tinham por base o culto religioso. Seu nome não tem posto saliente em nenhuma confraria ou irmandade católica do Rio de Janeiro; seu retrato não existe em nenhuma sacristia de igreja, entre os provedores jubilados ou irmãos beneméritos vestidos de opa. A esse tempo, era, entretanto, manifestação habitual de altruísmo e elemento de força social e política, governar irmandades e ordens terceiras.

Parece que a sua educação entre os ingleses explicaria, ao mesmo tempo, o seu acatolicismo, e o seu puritanismo e a sua tendência realista e realizadora; a energia corre por conta da procedência gaúcha" (Faria, 1926, p.108). 
Mas, para se ter uma idéia da real importância de Mauá para o desenvolvimento econômico brasileiro, transcrevem-se, a seguir, algumas de suas realizações, que estimularam outras afins, por parte de outros agentes.

"Estava lançada a semente benéfica. Dias antes, trinta e cinco dias apenas, esse mesmo realizador tinha substituído pela iluminação a gás as lâmpadas de azeite de peixe com que a Corte se iluminava desde o governo colonial do Conde de Rezende. O deslumbramento da luz do gás na Corte arrastou os ânimos timoratos e dentro em pouco, grande número de pequenas cidades do Brasil eram iluminadas a gás.

A mesma fascinação exerceu a Estrada de Ferro Mauá, sobre os homens públicos e sobre os homens de negócio em relação aos caminhos de ferro" (Faria, 1926, p.165166).

Apesar da influência que a religião exerce sobre o desenvolvimento ou não da economia, deve ressaltar-se que ocorre diminuição dessa influência, àmedida que avança o desenvo lvimento econômico.

Robert Barro, economista da Universidade de Harvard, em um trabalho recém publicado, dá suporte à hipótese, mencionada no parágrafo anterior, de que a religiosidade se reduz com o avanço econômico, hipótese chamada de secularização da eligião, principalmente quando tal avanço está associado ao aumento da urbanização, conforme pode ser observado no fragmento que segue, retirado de sua obra.

"Apesar de a religiosidade tender a se reduzir com o desenvolvimento econômico, a forma como isso se dá depende das dimensões do desenvolvimento econômico. Por exemplo, a religiosidade está positivamente relacionada com o nível de educação e negativamente relacionada com o nível de urbanização. $\mathrm{O}$ aumento da expectativa de vida e a redução na fertilidade são aspectos que se relacionam inversamente com o nível de 
frequência às igrejas, mas não parece ter associação nenhuma com o nível de crença religiosa" (Barro \& MacCleary, 2002, p.40).

O gráfico exposto a seguir ilustra a veracidade do parágrafo anterior.

Tabela 1. Evolução do percentual de urbanização e de pessoas sem religião.

Ano Porcentagem de urbanização Porcentagem de pessoas sem religião

\begin{tabular}{lll}
\hline 1890 & $\ldots{ }^{18}$ & $0,1 \%$ \\
1940 & $31,2 \%$ & $0,5 \%$ \\
1950 & $36,2 \%$ & $0,8 \%$ \\
1960 & $44,7 \%$ & $0,6 \%$ \\
1970 & $55,9 \%$ & $0,8 \%$ \\
1980 & $67,6 \%$ & $1,9 \%$ \\
1991 & & \\
& & \\
2000 & $81,3 \%$ & $5,1 \%$ \\
& & $7,5 \%$
\end{tabular}

Fonte: Censo Demográfico (1890, 1940, 1950, 1960, 1970, 1980, 1991, 2000)

Em outras palavras, o que Barro quer dizer é que a religião é um bem inferior ${ }^{19}$, istoé, à medida que a renda de uma nação aumenta, a religiosidade dela diminui. Entretanto, precisa-se ter cuidado com esta afirmação, pois o próprio autor, Robert Barro, ressalta que a conclusão não

\footnotetext{
${ }^{18}$ Este dado não foi localizado.

${ }^{19} \mathrm{O}$ bem inferior é aquele cuja quantidade demandada diminui, tudo mais mantido constante, quando a renda aumenta.
} 
é definitiva. Mesmo assim, ela é importante, pois, agregada à hipótese de Weber de que o Catolicismo não estimulou o desenvolvimento do "espírito do capitalismo", que, segundo o próprio Weber, estimula o desenvolvimento econômico, pode levar à conclusão de que o Catolicismo adotou uma postura, mesmo que de forma inconsciente, muito benéfica para si, quando comparada à do Protestantis mo, já que a religião tende a ser um bem inferior, menos desejado à medida que ocorre o desenvolvimento econômico. Essa conclusão parece ser confirmada por Iannaccone, em sua obra analisada mais a frente.

Além das conclusões descritas anteriormente, Robert Barro ressalta os seguintes resultados, em seu último trabalho empírico, feito com dados de diversos países, obtidos por meio de questionários preenchidos durante o período de 1981 a 1999, cujo objetivo foi medir o nível de frequência das pessoas às igrejas e a religiosidade nesses países.

A presença de uma religião estatal está positivamente relacionada com o nível de religiosidade das pessoas, provavelmente por causa dos subsídios recebidos do Estado. No entanto, a religiosidade é negativamente relacionada com o nível de regulamentação do mercado de religião e com a presença de governos comunistas, o que significa que, quanto maior a concorrência entre diversos tipos de religiões, a religiosidade apresentada pelas pessoas tende a aumentar, e que, na presença de governos comunistas, se apresenta uma situação de menor religiosidade das pessoas.

A análise mostrou, ainda, que o crescimento econômico parece estar positivamente relacionado a crenças religiosas, especialmente àquelas referentes a céu e inferno, mas negativamente àfrequência àigreja (Barro \& MacCleary, 2002, p.33).

Iannaccone propôs-se a fazer um estudo econométrico, com dados de frequência de fiéis a diversas igrejas, em diversos países, durante o período de 1991 a 1998, e chegou às seguintes conclusões: 
A primeira é que os E.U.A. são o país que detém a maior base de dados quando o assunto é religião, dados colhidos desde 1950; mas, mesmo assim, eles são suficientes apenas para rejeitar algumas teorias da secularização, mas não para responder quais os motivos que estão levando a religião a mudar de importância relativa, ao longo do tempo (Iannaccone, 2002, p.22).

O seu estudo mostrou também que, na Inglaterra, na Alemanha e na França, a teoria da secularização foi confirmada, ou seja, que, à medida que o desenvolvimento econômico ocorre a frequência à igreja declina. No entanto, nos E.U.A., a frequência às igrejas tem se mantido alta. Já em países católicos, como a Irlanda, a Polônia e as Filipinas, tem ocorrido a persistência da frequência alta, enquanto em países como a Noruega, o Japão e Israel, tem se mantido um nível de frequência baixa. Em países como a Áustria, a Suíça, o Canadá, a Itália e a Holanda, têm ocorrido períodos de declínio e de estabilidade, na frequiência de fiéis às igrejas (Iannaccone, 2002, p.25-26).

Iannaccone ressalta, ainda, que por um lado nenhum país analisado apresentou um crescimento constante na frequência à igreja e, por outro, que nenhum país com baixa frequiência à igreja apresentou qualquer indicação de aumento na mesma. Iannaccone afirmou, ainda, que alguns autores interpretam essa evidência como um forte subsídio para a teoria da secularização, e que governos repressivos são extremamente eficientes na redução da frequência às igrejas, ou seja, são extremamente eficientes, quando o assunto é secularizar a sociedade (Iannaccone, 2002, p.26).

Para dar mais força à teoria de que, à medida que o capitalismo evolui, o poder de influência da religião se reduz, transcreve-se, a seguir, uma passagem do livro de Max Weber.

"Temo que, toda vez que a riqueza aumenta, a religião diminui na mesma medida. Não vejo, daí, como é possível, na natureza das coisas, conservar durante muito tempo qualquer revivência da verdadeira religião. Porque a religião deve necessariamente 
produzir a operosidade, como o senso de economia, e essas só podem produzir riqueza. Quando esta aumenta, crescem o orgulho, a paixão e o amor ao mundo em todas as formas. Como será então possível ao Metodismo, isto é, a uma religião do coração, continuar neste sentido, por mais que agora esteja a florescer como uma árvore nova?" (Weber, 1905, p.126).

Camargo também menciona que o poder da religião sobre a sociedade se reduziu com a migração da população do campo para a cidade.

"Comparando o catolicismo tradicional rural e o urbano no Brasil, um contraste torna-se logo patente: o catolicismo urbano, diversamente do rural, não orienta efetivamente a conduta das pessoas, nem constitui o centro das determinantes valorativas da sociedade.

No mundo urbano, a religião tradicional católica é relegada a uma esfera da realidade ritualística e superficial que se desvincula dos valores e conhecimentos que no passado serviram para orientar a vida e pautar o comportamento. As decisões fundamentais da existência, no meio urbano, 政 orientadas por valores profanos característicos de uma sociedade competitiva e de uma ética leiga. Persiste, evidentemente, o comportamento religioso do tipo rural nas áreas urbanas. Analisa-se, de acordo com a metodologia adotada, o processo típico de urbanização e de secularização, como ocorre na sociedade brasileira" (Camargo, 1971, p.18).

Esse item dá-nos fortes indícios teóricos e empíricos de que a religiosidade, de forma geral, se reduz com o desenvolvimento econômico, ou seja, a tese da secularização está se mostrando consistente até o presente momento. Essa conclusão instiga-nos a direcionar este trabalho, a partir do item 4, para a questão da influência de aspectos seculares sobre a igreja católica brasileira, haja vista que a influência da religião sobre a sociedade economicamente desenvolvida parece estar se reduzindo, conforme pudemos observar nas teses de Camargo e de Weber, e nos estudos empíricos de Barro e de Iannaccone. 
Mas, antes de encerrar este item e de estruturar uma conclusão sobre as diversas linhas de estudo sobre o tema "economia e religião", gostaríamos de ressaltar uma outra curiosidade abordada neste item. Trata-se de lembrar que, considerando a veracidade da tese da secularização e a política de condenação ao uso de contraceptivos que a Igreja católica adota, e ainda o fato de que, quanto maior o número de pessoas, maior a dificuldade de se produzir desenvolvimento econômico para todos, haja vista que os recursos econômicos são limitados, pode-se observar que, muito provavelmente, de forma inconsciente, a Igreja católica tem adotado uma política prejudicial a ela, do ponto de vista econômico, mas com total sentido, do ponto de vista doutrinário e da tese da secularização.

\subsection{Linhas de pesquisa sobre o tema "economia e religião"}

Neste item, sintetiza-se as principais linhas de pesquisa sobre o tema "economia e religião", ressaltando as principais preocupações dos mais importantes autores que estudam o tema em questão. Acredita-se que, através dessa síntese será mais fácil visualizar a importância desse trabalho.

A linha de pesquisa com maior número de estudiosos trata da relação de influência que as diversas religiões mantêm com o desenvolvimento do capitalismo.

Quando analisou a relação de influência do Catolicismo sobre o capitalismo, Max Weber foi o primeiro pensador a se preocupar com o assunto. Ele ressaltou que o Catolicismo não exerce influência positiva sobre o capitalismo, ou seja, a influência que o Catolicismo exerce sobre o capitalismo acaba prejudicando o seu desenvolvimento pleno. É importante ressaltar que Werner Sombart, Amintore Fanfani, Daniel Fusfeld, Charbonneau, Ekelund e Guiso compartilham da idéia de Weber, nesse sentido. Luís Corrêa Lima é o único teórico que apresenta o Catolicismo como positivo para o capitalismo, mas, para tanto, considera o capitalismo mercantilista do século XV, e não o capitalismo do século XIX, que Weber estuda. 
Quando passou a analisar o Protestantismo nesse mesmo contexto, Weber também aparece como o primeiro e principal pensador a se preocupar com o assunto, ressaltando que o Protestantismo teve um papel determinante no estabelecimento do "espírito do capitalismo", ou seja, criou a base para a disseminação do capitalismo. Amintore Fanfani, apesar de não concordar com Weber na intensidade da influência do Protestantismo sobre o capitalismo, concorda na direção, ou seja, ele acredita que o Protestantismo acabou exercendo uma influência positiva sobre o capitalismo. Daniel Fusfeld, Guiso, Robert Woodberry, Charbonneau e Ekelund compartilham das idéias de Weber. Fusfeld ressalta, ainda, que talvez essa influência negativa do Catolicismo sobre o capitalismo tenha estimulado a Reforma Protestante. Robertson e Kurt Samuelsson são os maiores representantes da idéia de que o Protestantismo não teve influência efetiva sobre o desenvolvimento do capitalismo. Na verdade, eles não acreditam que qualquer religião exerça poder de influência sobre o capitalismo.

O Judaísmo é ressaltado por Werner Sombart como uma religião que exerce influência sobre o capitalismo ainda mais positiva do que o Protestantismo. Sombart chega a afirmar que o Protestantismo recebeu influências doutrinárias do Judaísmo e, devido a esse fato, esta religião também exerce influência positiva sobre o capitalismo. Guiso elabora um trabalho empírico que parece confirmar a idéia de que o Judaísmo é positivo para o desenvolvimento do capitalismo.

Rachel McCleary ressalta que o Budismo e o Hinduísmo possuem, em sua doutrina, princípios que acabam atrapalhando o desenvolvimento do capitalismo, enquanto as religiões islâmicas não, isto é, sua doutrina apresenta aspectos interessantes para o desenvolvimento do capitalismo.

Com o objetivo de sistematizar e de concluir as idéias dessa linha de pesquisa, apresentase, a seguir, um quadro onde são resumidas as questões aqui abordadas.

Tabela 2. O pensamento de alguns estudiosos sobre a influência que algumas religiões exercem sobre o capitalismo. 


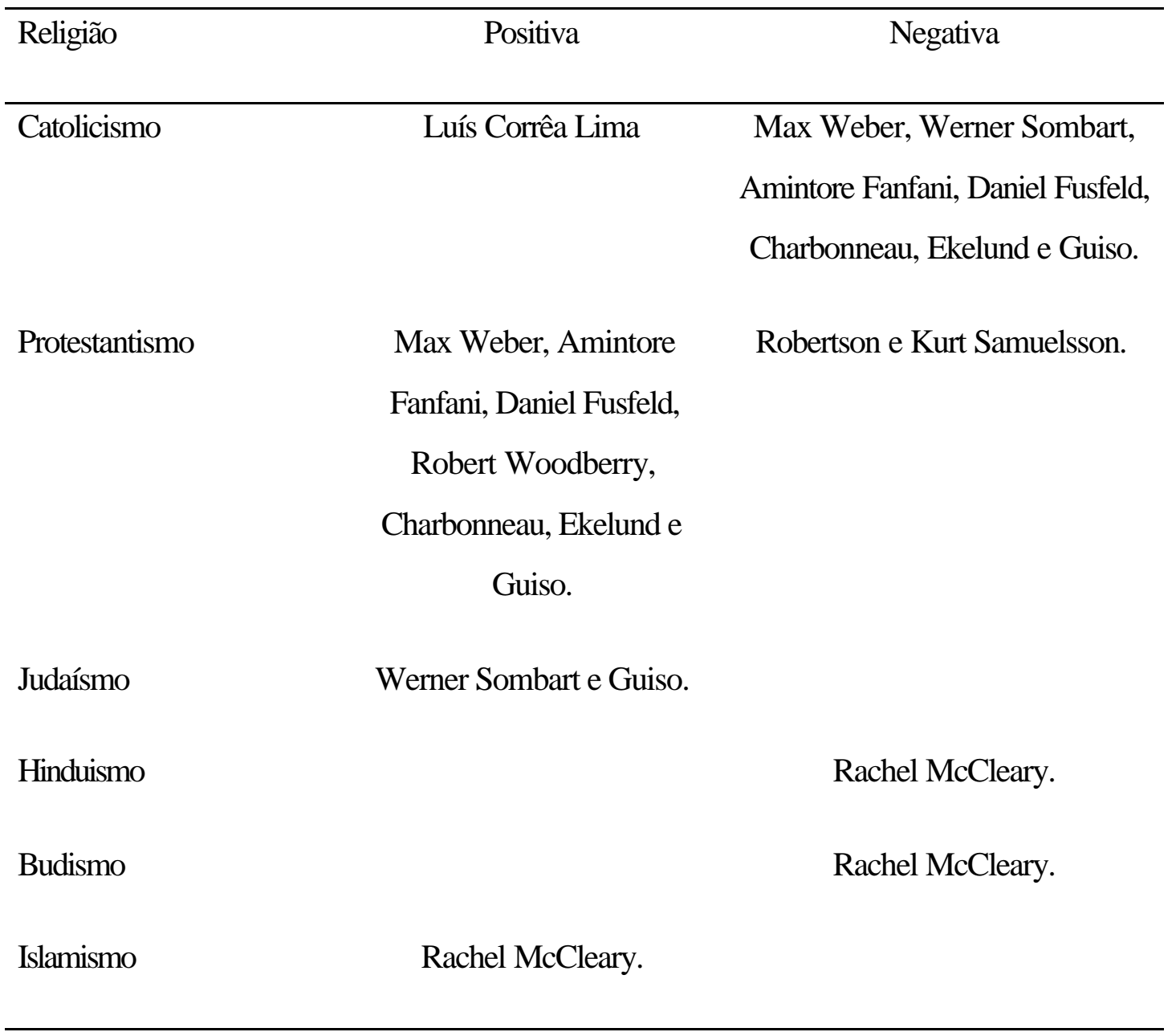

Quando o assunto é a questão da secularização, levantada por Max Weber, autores contemporâneos, como Barro e Iannaccone, estão encontrando indícios da veracidade da tese da secularização, de que, à medida que a sociedade evolui economicamente, a religiosidade tende a se reduzir. É obvio, no entanto, que, dentre as várias conclusões referidas nesses trabalhos, há variações em torno dessa confirmação. No entanto, não foi encontrado nenhum trabalho, nem teórico, nem empírico, que apresentasse argumentos fortes o suficiente para derrubar a tese da secularização.

Este trabalho pode ser enquadrado na primeira linha de pesquisa referida neste item. No entanto, guarda uma particularidade: por se preocupar com o comportamento da Igreja católica 
frente a questões seculares, e não o oposto, a influência que a Igreja católica exerceu e exerce sobre a sociedade, trata-se de um trabalho incomum, mas já estimulado por Max Weber em sua tese "A ética protestante e o espírito do capitalismo". Contudo, a abordagem aqui adotada é muito mais restrita do que a de Max Weber e de autores aqui citados, pois, enquanto esses autores analisam a relação entre o secular e a religião, este trabalho analisará apenas a relação entre o secular e a Igreja católica brasileira, enquanto instituição. Isso significa que desconsideramos os aspectos doutrinários da questão. 


\section{A RELAÇÃO DA IGREJA CATÓLICA BRASILEIRA COM ALGUMAS QUESTÕES SECULARES}

Quando se pensa em economia e religião no Brasil, pensa-se primordialmente em economia e Catolicismo, tal o poder de influência que essa religião ainda exerce sobre a sociedade brasileira. Nesse sentido, cabe a tese central abordada por Weber sobre o poder reduzido que essa religião exerceu sobre o estímulo ao desenvolvimento do "espírito capitalista". Entretanto, o Catolicismo brasileiro tem suas especificidades e elas se apresentam no posicionamento da Igreja católica, perante acontecimentos seculares de cunho econômico e político. É por esse motivo que, a partir deste momento, será estudado o posicionamento dessa instituição perante acontecimentos seculares importantes.

Em princípio, é importante deixar claro que a análise de uma instituição como a Igreja católica não é necessariamente igual a uma análise da doutrina da religião católica. Esta afirmação pode parecer estranha, mas é indispensável e corresponde a uma preocupação comum de estudiosos do tema, conforme se pode observar no excerto que segue.

"Um postulado básico bem estabelecido pela análise institucional contemporânea e pelos estudos sociológicos clássicos diz que qualquer exame da Igreja e da política deve levar em consideração o caráter institucional da primeira. A fé é um fenômeno supra - racional se proclama pairar sobre todos os outros valores. A Igreja tem início nessa fé, mas, como toda instituição, ao desenvolver interesses, então tenta defendê-los. O objetivo principal de qualquer Igreja é propagar sua mensagem religiosa. Todavia, dependendo da percepção que tenha dessa mensagem, pode vir a se preocupar com a defesa de 
interesses tais como sua unidade, posição em relação às outras religiões, influência na sociedade e no Estado, o número de seus adeptos e sua situação financeira. Quase toda instituição se preocupa com a própria preservação; muitas tratam de expandir. Essas preocupações facilmente levam à adoção de métodos que são inconsistentes quanto aos objetivos iniciais" (Mainwaring, 1989, p.15-16).

A partir dos parâmetros estabelecidos no parágrafo anterior, iremos direcionar nossa análise, ou seja, nos preocuparemos em analisar o comportamento da Igreja católica brasileira em situações seculares, como concorrência, Igreja e Estado, situação financeira e outros aspectos, conforme segue.

Esta análise da Igreja católica parte do mesmo princípio que pauta a maioria dos estudos de autores brasileiros que abordam o tema em questão. Ela parte do princípio de que as mudanças da Igreja resultam de suas tentativas de defender seus interesses, de aumentar o número de praticantes e de preservar a instituição (Mainwaring, 1989, p.18).

A afirmação acima, justifica-se no parágrafo que segue.

“João Paulo II, quando esteve no Brasil em 1991, atento à diminuição de seu rebanho e ao crescimento dos concorrentes, cobrou dos cerca de 300 bispos reunidos em Natal durante o congresso Eucarístico Nacional uma ação mais eficaz contra a ignorância religiosa e a carência de doutrina que deixam o povo vulnerável à sedução das seitas" (Mariano, 1999, p.13).

Tem-se plena consciência de que uma análise como essa desconsidera aspectos doutrinários / religiosos, que também direcionam as decisões da Igreja católica brasileira. Mas essa análise das decisões da Igreja católica, em relação à sua doutrina, dependem de um profundo conhecimento do assunto, que não é relevante para o tratamento secular do tema. A presente análise tem como objetivo, contudo, apenas ressaltar que aspectos seculares acabam influenciando as decisões da Igreja católica. Por esse motivo, desconsiderar a coerência do 
comportamento secular dessa instituição, em relação à sua doutrina, não cria qualquer tipo de obstáculo a que se atinja esse objetivo.

\subsection{A transição do sistema monárquico para o republicano e a Igreja católica brasileira}

A transição do Império para a República causou uma série de impactos sobre a Igreja católica brasileira. Foi um dos períodos mais traumáticos para a instituição, causado pelo processo de separação entre Estado e Igreja. Para entender melhor esse processo, serão abordados, no item 4.1.1, os motivos do rompimento entre o Estado e a Igreja católica brasileira, e, no item 4.1.2, será analisada a relação entre o Estado brasileiro e a Igreja católica no final do período imperial e no início do período republicano.

\subsubsection{Motivos que levaram ao rompimento entre o Estado republicano e a Igreja católica no Brasil}

Com base no estudo de diversos autores, como Mainwaring, Lustosa, Lima, Costa, Torres, Rodrigues, Pereira e outros, pode-se considerar dois motivos principais para o rompimento entre o Estado republicano e a Igreja católica brasileira: os ideológicos e os financeiros.

Dentre os motivos ideológicos, devemos ressaltar a perda da função que a Igreja católica exercia no sistema imperial, onde se colocava como a única representante legal do poder divino. Por meio desse poder, plenamente aceito pela sociedade, ela pregava que o poder da família imperial era um poder concedido por Deus, ou seja, a Igreja católica fazia o papel de justificativa legal e incontestável do poder do imperador. A partir do momento em que surge a República e a escolha do representante maior da nação passa a ser feita através do voto, a Igreja perde sua principal função para o Estado e passa a ser dispensável. 
O motivo ideológico estava calcado também na questão da liberdade individual, inclusive de culto religioso, defendida pelos republicanos, conforme explica a seguir o historiador Oscar F. Lustosa.

"Nesse quadro de modernização da sociedade, não se deve esquecer que o ideal político do liberalismo pretendia, com o regime republicano, estabelecer uma forma de governo e um esquema político no qual as liberdades do indivíduo ou melhor da pessoa fossem prioritárias e privilegiadas e o Estado se tornasse simples e exclusivamente defensor das mesmas. A visão de progresso que dominava as camadas cultas do país exigia, na linha do que fora a pregação e a propaganda do ideal republicano, um posicionamento do Estado inteiramente dominado pela mentalidade do liberalismo, criando um estatuto legal que não atingisse, sob nenhum pretexto, os direitos do cidadão brasileiro.

É por aí que se pode compreender como a República, no plano religioso, nasce e se implanta, no Brasil, sob o signo liberal do laicismo. Dominante durante quarenta anos, o Estado laico brasileiro facilitará, por incrível que pareça, a mudança da situação da Igreja Católica em nosso país. Completamente separada do governo que abriu espaço para o exercício livre de todas as denominações religiosas, ao lado do aparelho estatal, que a marginalizava, a Igreja não descuida de trabalhar as elites dirigentes do país, e de se apoiar na força dos latifundiários embora todos eles impregnados de mentalidade liberal em matéria religiosa. $\mathrm{O}$ apoio das elites e dos grupos dominantes, ocasional que seja, é um dado importante na estratégia da hierarquia e pode tornar-se trampolim para chegar às áreas governamentais" (Lustosa, 1991, p.9-10).

Existe ainda o motivo financeiro. É impossível negar que o desligamento entre a Igreja e o Estado proporcionou um enorme alívio financeiro ao recém instalado Estado republicano, conforme pode ser observado na descrição de diversos autores que estudam o tema e que ressaltam a preocupação da Igreja católica brasileira com a questão financeira, quando dessa separação. Esse alívio financeiro deurse principalmente devido ao fato de o Estado ficar 
desobrigado de pagar a côngrua, ou seja, o salário dos padres, e também de ajudar na manutenção e na ampliação das paróquias.

"A nova situação, inesperadamente estabelecida, suscita para a hierarquia eclesiástica católica uma série de problemas que vão desde o mal-estar em face às ideologias modernas que parecem dominar, até às preocupações financeiras que desnorteiam a vida cotidiana das dioceses e freguesias" (Lustosa, 1991, p.15).

Alguns autores, inclusive Weber, apontam o Catolicismo como um desestímulo ao desenvolvimento pleno do capitalismo. Face a essa situação, podemos entender porque muitos capitalistas, quando chegaram ao poder através do sistema republicano, exigiram a dissociação ente o Estado e a Igreja católica (Lima, 2001, p.266).

A afirmação acima não parece fazer parte da realidade brasileira, haja vista que não foram propriamente capitalistas, com idéias puritanas, que implementaram o sistema republicano no Brasil, e sim militares e intelectuais, com o apoio do Exército, e de alguns capitalistas incipientes. Considerando esses fatos, a questão da ideologia e a questão financeira parecem explicar muito melhor os motivos da dissociação entre o Estado e a Igreja católica.

Com o objetivo de sistematizar, de forma conclusiva, os motivos dessa dissociação entre o Estado e a Igreja católica brasileira, durante a transição do sistema monárquico para o republicano, focalizam-se os de natureza ideológica e financeira, tais como, a perda da função que a Igreja católica exercia na monarquia, a questão da liberdade individual e do laicismo dos Estados republicanos e, por último, o alívio financeiro ao Estado republicano, decorrente desse rompimento com a Igreja católica, haja vista que o Estado monárquico a ajudava financeiramente.

Por último, vale a pena lembrar que, no Brasil, a dissociação entre o Estado e a Igreja católica não parece estar relacionada com uma questão muito comum na Europa, que se trata de capitalistas puritanos chegarem ao poder através do sistema republicano e exigirem a separação 
entre o Estado e a Igreja católica, uma vez que esta instituição tendia a atrapalhar o desenvolvimento pleno do capitalismo, conforme ressaltado por Weber e por outros.

\subsubsection{A relação entre o Estado brasileiro e a Igreja católica}

$\mathrm{Na}$ afirmação a seguir transcrita, pode-se notar uma associação entre as classes dominantes do fim do século XIX, as idéias capitalistas e as idéias republicanas. Foi essa associação, agregada à propagação dessas idéias por intelectuais da época, juntamente com o descontentamento das Forças Armadas com o Império, que viabilizaram o surgimento do sistema republicano:

"Na segunda metade do século, no entanto, os empreendimentos empresariais seriam melhor vistos, à medida que os próprios fazendeiros se convertem, em certas áreas, numa espécie de empresário, introduzindo melhoramentos em suas fazendas, tentando substituir o escravo pelo trabalhador livre, aperfeiçoando os métodos de beneficiamento, associando-se a empresas industriais, investindo em ferrovias e organizações bancárias, assumindo atitudes progressistas em matéria de política, vendo com simpatia as idéias emancipadoras, e aderindo a idéias republicanas. O processo evidentemente não é generalizado, tendo atingido apenas aquelas áreas de maior produtividade, e onde a acumulação de capital se dava em ritmo acelerado" (Costa, 1977, p.200-201).

"Por todas essas razões as principais reformas realizadas no período, tais como abolição e república, resultaram de uma ação conjunta dos grupos urbanos, aliados aos grupos mais progressistas das zonas rurais" (Costa, 1977, p.204).

Com o surgimento do capitalismo no Brasil e também do período republicano, os liberais entraram em cena com suas idéias que se chocaram com as idéias defendidas pela Igreja católica. Enquanto os liberais defendiam a liberdade econômica, através da liberdade de consciência, de 
culto e da verdade, a Igreja pregava justiça social, a detenção da verdade absoluta pela Igreja e o poder de regular as relações humanas. Ver-se-á mais à frente que os interesses de ambas as partes nem sempre eram tão nobres assim. Por enquanto, pode ser ressaltado o seguinte aspecto dessa luta de interesses:

"Se na questão da liberdade de consciência os liberais conseguiram ver suas idéias grandemente vitoriosas e afinal em tese reconhecidas pela igreja, e oficialmente adotada pelo Vaticano - declaração Dignitatis Humanae - igualmente os católicos venceram e ninguém, hoje, nega os princípios da subordinação das relações econômicas à regra da justiça" (Torres, 1968, p.108).

Esse posicionamento antagônico entre os liberais e a Igreja católica se dava principalmente porque os primeiros calcavam as suas idéias na questão científica, enquanto o segundo grupo defendia o seu ponto de vista embasados na questão da fé. O problema maior estava no fato de cada grupo acreditar que as suas justificativas eram superiores às do outro grupo.

Apesar desse posicionamento antagônico, destacado no parágrafo anterior, Torres ressalta uma mudança no posicionamento da Igreja católica mundial, deixando-se influenciar pelo novo poder econômico que surgia com o capitalismo. Isso aconteceu com a saída do papa Pio IX e a entrada do papa Leão XIII (Torres, 1968, p.164-167).

Mas esse processo de convivência pacífica com as idéias liberais não foi tão simples e rápido assim. Antes do estabelecimento dessas idéias, havia muitos conflitos entre a Igreja e o Estado brasileiro, que se mantiveram no início do período republicano e somente depois se transformaram e permitiram um convívio um pouco mais pacífico. Para ilustrar e esclarecer esse fato, transcreve-se um excerto que analisa a relação Estado - Igreja católica, ainda no período monárquico: 
"Roma concedeu ao Imperador os direitos de padroado da Ordem de Cristo mas não assinou nenhuma concordata, de modo que a concessão, a seus olhos, assumia caráter temporário. Era um "modus vivendi" no qual Roma apenas tolerava o Padroado no Brasil. Na prática, o Padroado resultaria numa inversão da ordem dos poderes, de acordo com a doutrina da Igreja, ficando o poder espiritual submetido ao poder temporal. Sendo o Estado quem pagava ao clero, ficava este equiparado ao funcionalismo público" (Rodrigues, 1981, p.3).

O bispo do Pará, Dom Macedo Costa, em 1863, dirigindo-se ao imperador, faz reclamações quanto à ingerência do Estado sobre os assuntos religiosos. Ele menciona que o fato de o Estado prover de recursos financeiros a Igreja católica não lhe dá o direito de tratar seus membros como funcionários públicos, colocando, portanto, a Igreja numa situação de inferioridade (Pereira, 1982, p.36-39).

"O Estado fazia à igreja exigências que esta não fazia ao Estado. A igreja, por exemplo, não reclamava do governo civil a nomeação dos ministérios. Mas o Estado, porque ajudava financeiramente o culto e pagava a côngrua, se achava com o direito de exigir que os párocos fossem zelosos, que os bispos cumprissem as ordens oficiais do governo, que a vida religiosa, em suma, de algum modo se submetesse à vida civil. E foi tudo isso que gerou, desde o princípio, uma série de equívocos, de mal-entendidos, suscetíveis de criar um ambiente de insegurança espiritual, que foi, até certo ponto, o clima todo do segundo reinado" (Pereira, 1982, p.253).

"O ofício acima vem mostrar que o governo ajudava as igrejas, provendo às suas necessidades materiais (reformas nas igrejas), cabendo às assembléias provinciais atender às despesas com as catedrais. Naturalmente que havia maior ou menor boa vontade. A tese fundamental era a mesma: o Estado ajudava os "empregados públicos" da igreja e esse vínculo é que criava o pressuposto da função, pela qual o poder espiritual, no caso brasileiro, ficava fundido ao poder temporal" (Pereira, 1982, p.256-257). 
Apesar da intensa crítica da Igreja católica brasileira ao poder imperial, quando do início do sistema republicano e da separação da Igreja católica do novo poder vigente, a mesma solicita a todos os seus fiéis que lutem contra essa separação e mantém essa postura durante grande parte da primeira metade do século XX. Isso denota a importância do poder político e d aspecto financeiro nas decisões ideológicas da Igreja católica brasileira. No entanto, é importante lembrar que a Igreja católica, como toda instituição de grande porte, tinha em seus quadros padres que desejavam a separação entre a Igreja católica e o Estado (Rodrigues, 1981, p.8592).

A preocupação da Igreja católica brasileira com tal ruptura não era infundada, pois, há uma relação direta entre o subsídio que uma religião estatal recebe e seu poder de influência sobre a sociedade (Barro \& MacCleary, 2002, p.40).

Tal preocupação também é ressaltada por Oscar Lustosa, conforme veremos a seguir:

"A nova situação, inesperadamente estabelecida, suscita para a hierarquia eclesiástica católica uma série de problemas que vão desde o mal-estar em face às ideologias modernas que parecem dominar, até às preocupações financeiras que desnorteiam a vida cotidiana das dioceses e freguesias. Donde, em consequência normal, jorra um clima de desconfiança para com o novo regime e uma atmosfera de insegurança em relação às possíveis condições de precariedade econômica e financeira em que se enredará a administração eclesiástica" (Lustosa, 1991, p.15).

Um marco na história da Igreja católica brasileira foi 07 de janeiro de 1890, logo após o término do Império, sistema com o qual a religião católica guardava relações espinhosas e estreitas ao mesmo tempo, quando Rui Barbosa, através do decreto n. 119A, estabeleceu a separação total entre a Igreja e o Estado (Lustosa, 1991, p.17).

Com o início da República, a Igreja católica perdeu benefícios financeiros de grande importância, perdeu o monopólio do ensino religioso nas escolas estaduais e uma relação 
privilegiada frente às demais Igrejas, quando o assunto era o poder político e econômico. Portanto, pode-se considerar 1890 a data da privatização da Igreja católica brasileira, a data do término do subsídio estatal e a data da quebra do seu monopólio em serviços como o da educação. Medidas como essas geraram maior concorrência e a necessidade de ajustes estruturais da Igreja católica, para se adaptar a um poder de mercado reduzido.

"De um modo geral, entre 1890 e 1916 a Igreja se preocupou sobretudo com a consolidação de reformas internas, mas alguns líderes começaram a promover uma presença mais marcante na sociedade, antecipando o modelo da neocristandade. $\mathrm{O}$ surgimento do modelo da neocristandade pode ser datado de 1916, mas os vinte e cinco anos precedentes se caracterizam por adaptações institucionais aos desafios de existir numa república secular" (Mainwaring, 1989, p.42-43).

A questão da separação entre o Estado e a Igreja católica brasileira se torna ainda mais problemática se forem consideradas as idéias de Ekelund, que afirma que o monopólio detido por igrejas estatais acarreta ineficiência por parte das mesmas, fato que acaba abrindo a possibilidade da entrada de concorrentes mais eficientes do ponto de vista econômico, com a extinção do monopólio.

"Religiões estatais monopolistas são ineficientes em muitos aspectos, por isso abrem a possibilidade de entrada de outros competidores mais eficientes" (Ekelund et al., 2002, p.647).

Face à separação entre o Estado e a Igreja católica brasileira, pode-se notar a situação abaixo descrita, quando o assunto é a influência de aspectos econômicos sobre esta instituição.

Com a queda do subsídio do Estado, e considerando o crescimento da população brasileira, de 14.333.915, em 1890, para 174.260.820, em 2002, segundo dados do Instituto Brasileiro de Geografia e Estatística - IBGE, a expansão das funções da Igreja católica no Brasil, na mesma proporção da população, ficou quase impossível. Outro motivo para isso diz respeito 
aos seus templos, que foram construídos, ao longo do século $\mathrm{XX}$, segundo as mesmas características suntuosas que detinham os templos construídos em épocas de recursos fartos, leia-se Império, criando-se dificuldade na manutenção financeira desses templos até os dias atuais. Considerando esses dois fatos, a queda do subsídio estatal e as construções suntuosas de difícil manutenção financeira, pode-se observar que dois aspectos econômicos frearam o seu crescimento e abriram espaço para igrejas concorrentes. Contudo, isso ressalta também a falta de convicção religiosa do povo brasileiro, uma vez que essa migração de uma religião para outra não deveria ser tão natural assim, se, de fato, os fiéis católicos fossem fervorosos.

Esses acontecimentos, por outro lado, reduziram o poder de influência da Igreja católica sobre a população brasileira, haja vista sua incapacidade de expandir-se na mesma proporção do crescimento vegetativo da população, conforme é evidenciado pela tabela a seguir. 
Tabela 3. Distribuição percentual da população segundo a religião no Brasil.

\begin{tabular}{cccccc} 
Anos & Católicos & Evangélicos & Espiritas & Outras & Sem Religião \\
\hline 1872 & 99,7 & $\ldots$ & $\ldots$ & 0,3 & $\ldots$ \\
1890 & 98,9 & 1,0 & $\ldots$ & 0,0 & 0,1 \\
1940 & 95,0 & 2,6 & 1,1 & 0,8 & 0,5 \\
1950 & 93,5 & 3,4 & 1,6 & 0,8 & 0,8 \\
1960 & 93,1 & 4,0 & 1,4 & 1,0 & 0,6 \\
1970 & 91,8 & 5,2 & 1,3 & 1,0 & 0,8 \\
1980 & 89,0 & 6,6 & 1,3 & 1,2 & 1,9 \\
1991 & 83,3 & 9,0 & 1,6 & 1,0 & 5,1 \\
2000 & 73,6 & 15,4 & 1,4 & 2,1 & 7,5 \\
\hline
\end{tabular}

Fonte: Censo Demográfico (1872, 1890, 1940, 1950, 1960, 1970, 1980, 1991, 2000)

A Igreja católica brasileira estava tão acostumada a ficar ao lado do poder, que, quando surgiu a República, determinado grupo dentro da instituição criou o Centro Católico, entre cujos objetivos constava a criação de um partido político católico. Mas o papa Pio XI interveio, proibindo tal ação (Rodrigues, 1981, p.103-109). 
Analisando esses fatos, pode-se perceber a importante influência que aspectos econômicos e políticos exercem sobre a postura da Igreja, sendo essas variáveis uma das que determinam que se expanda ou que se retraia essa instituição.

Analisando a relação da Igreja católica brasileira com o Estado monárquico e com o Estado republicano, pode-se perceber que, no período monárquico, o Estado brasileiro financiava a Igreja católica e, devido a tal fato, sentia-se no direito de interferir nesta instituição. Isso acabava causando uma série de desentendimentos entre as duas instituições. Entretanto, quando da separação, a Igreja católica pede a todos que lutem contra tal situação, conforme explicitado por Rodrigues (Rodrigues, 1981, p.85-92).

Com o surgimento da República e a separação entre o Estado e a Igreja, o relacionamento conflituoso entre as duas instituições termina, e a Igreja católica fica livre para se preocupar mais intensamente com aspectos doutrinários. No entanto, seu poder de mercado se reduz e isso se reflete no aumento de Igrejas concorrentes e na queda da porcentagem de fiéis, conforme será visto nos itens a seguir.

\subsection{A concorrência direta $e$ a indireta}

Apesar de a igreja católica brasileira ter experimentado, apenas a partir de 1980, uma queda mais acentuada na porcentagem de fiéis, desde o surgimento da República, abriu-se um espaço maior para a concorrência direta, ou seja, a concorrência com outras religiões. O aumento na concorrência indireta, ou seja, a concorrência com outras instituições seculares, como clubes, sindicatos, partidos políticos, etc., deve-se muito mais ao processo de migração em massa para as cidades. Esses aspectos serão estudados mais profundamente a seguir; nos itens 4.2.1, 4.2.1.1 e 4.2.2. 


\subsubsection{O aumento na concorrência direta}

O aumento na concorrência direta, conforme já foi explicitado, decorre do aumento na quantidade de instituições religiosas. Os motivos que levaram ao aumento dessa concorrência, são de cunho econômico e político e surgiram através da instituição da República. Esses motivos já foram explicitados no item 4.1. No entanto, serão ressaltados a seguir.

Com o surgimento da República, ocorre a "privatização" da Igreja católica brasileira, o término do subsídio estatal e a quebra do seu monopólio em serviços como o da educação. Medidas como essas geram maior concorrência e a necessidade de ajustes estruturais da Igreja católica, para se adaptar a um poder de mercado reduzido.

Apesar dessa abertura religiosa que a República proporcionou, o Estado continuou a guardar relações de proximidade com a Igreja católica. Essas relações impediam um crescimento maior da concorrência, conforme se pode notar no episódio dos cultos africanos, descrito a seguir.

"Era costume, até pouco tempo (década de 1950), se extinguirem policialmente os cultos africanos no Brasil, apenas há menos de dez anos vindo a lhes ser garantido o livre funcionamento com base na letra da Constituição. Pesquisas que realizamos no Recife, especialmente para este estudo, permitiram-nos saber da existência de inúmeras dessas organizações no século passado, várias delas entretidas pelos negros libertados pelos cruzeiros ingleses depois de 1850, mas todas funcionando clandestinamente e sempre sob a ameaça de repressão policial" (Ribeiro, 1982, p.47-48).

A afirmação acima permite observar um fenômeno no campo religioso semelhante aquilo que os economistas chamam de imposição de uma barreira à entrada, um limitador à concorrência, garantindo uma reserva de mercado, no caso, à Igreja católica br asileira. 
Com o intuito de identificar a influência sobre o desempenho da Igreja católica da retirada das barreiras aos cultos afro-brasileiros, insere-se a seguir um trecho da obra de René Ribeiro, que remete sua análise a tabela 3 da página 46.

"É de suspeitar que no caso do espiritismo e das outras religiões haja um interrelacionamento devido à preferente auto-identificação dos umbandistas como espíritas na época da grande expansão desta religião (1940/50) e à declaração franca de sua confissão religiosa no período 1950/70, época de consolidação e reconhecimento social dessa nova religião, saída da desprezada macumba” (Ribeiro, 1982, p.276).

A concorrência das demais religiões sempre foi uma preocupação da Igreja católica brasileira. Ela se intensificou à medida que essa concorrência começou a ameaçar sua hegemonia. Em 1953, criou-se o Secretariado Nacional para a Defesa da Fé e da Moralidade, cujo objetivo era vigiar a marcha das falsas religiões, condenar movimentos e falsas idéias e a expansão da imoralidade e da amoralidade na vida pública e particular. O movimento dava início a uma campanha contra o espiritismo porque, de acordo com os bispos, o Espiritismo nega não apenas uma ou outra verdade de nossa Santa Religião, mas todas elas (Mainwaring, 1989, p.54).

A importância de questões de cunho econômico no aumento da concorrência pelos fiéis é levantada por dois padres que também são economistas, conforme segue:

'Num artigo com título 'Concorrência por fiéis no mercado de religiões', publicado no diário 'O Estado de São Paulo' de 17/06/92, p.2, o economista Fernando Antônio Hadba interpreta a proliferação das seitas no quadro de uma análise econômica. No mercado das religiões (cristãs no Brasil), o produto é o caminho da salvação e os consumidores são todos os que precisam de uma crença. Até alguns anos atrás, havia um só grande ofertante que monopolizava o mercado: a Igreja católica. Este monopólio, porém, acabou sendo desafiado pelas seitas. 'Enquanto a Igreja católica se envolve em questões laicas as novas Igrejas se voltam para os desejos de seus fiéis pela salvação', e 
aumentam sua faixa de mercado. A insensibilidade do produtor de bens religiosos às expectativas do consumidor desses bens leva à perda do monopólio e à emergência de um sistema concorrencial que força o produtor dominante a se adaptar. 'Qualquer empresa que enfrentasse uma situação como a da Igreja católica no Brasil de hoje buscaria mudanças na sua estrutura'. Por outros caminhos, muitos católicos chegaram à mesma conclusão; hoje, dá-se importância ao respeito a religiosidade popular, à acolhida fraterna dos fiéis, ao reconhecimento da autonomia (e complexidade) das ciências sociais, à atitude humilde em relação ao secular, etc. A propensão hegemônica do econômico a explicar os comportamentos sociais incomoda e irrita; não há porém como negar que muitos desses modelos apresentam um alto grau de performância explicativa e previsional" (Vos \& Vervier, 1997, p.184).

Mainwaring também afirma que o aumento da concorrência veio influenciar as decisões da Igreja católica no Brasil, que sempre desdenhou as práticas religiosas populares. Mas, a partir de 1920 e 1930, quando o Espiritismo e o Protestantismo começaram a crescer, a Igreja católica passou a ter maiores preocupações com as práticas religiosas populares, antes tratadas por ela como ignorância religiosa. Afirma também que a Igreja só se preocupou com a missão pastoral quando sua influência junto ao Estado se viu ameaçada, sua atuação no sistema educacional se esvaziou, a competição com outras seitas e religiões foi se ampliando e quando alguns valores católicos tradicionais ruíram (Mainwaring, 1989, p.50-53).

Portanto, pode-se ressaltar que o aumento da concorrência direta deve-se, em grande parte, ao término da situação privilegiada que a Igreja católica detinha ao usufruir da situação de única Igreja estatal. Com o fim desse benefício, surgiram diversas Igrejas buscando satisfazer os desejos dos fiéis católicos descontentes e, com isso, se estabeleceram no mercado, conforme pode ser observado na tabela 3, página 46. A Igreja católica, por outro lado, demorou a se adaptar e a dar atenção a esses desejos, haja vista que mudar a cultura de uma instituição do 
porte da Igreja católica brasileira é um processo extremamente lento, até porque ela é uma das instituições mais conservadoras que existem.

\subsubsection{O aumento na concorrência direta e a contribuição das idéias de Ekelund}

Apesar de o tratamento das relações entre Igrejas e fiéis como um mercado econômico ser extremamente discutível, e a análise do comportamento cultural desses dois agentes ser muito interessante e abrangente, é cada vez mais comum analisar o comportamento microeconômico desses agentes. Na própria Igreja católica, existem padres como Vos e Vervier que já aceitam esse tipo de análise. Face a esse motivo, serão utilizado os conhecimentos de Ekelund, explícitos no capítulo 3, item 1.1, para analisar a Igreja católica brasileira.

Apesar da expressiva perda de fiéis que a Igreja católica brasileira experimentou, no último século, para as Igrejas pentecostais e neopentecostais, as idéias de Ekelund dão suporte para não acreditar que se trate de uma tendência. Ekelund afirma que Igrejas que cobram caro pelo seu serviço objetivam expurgar, ao máximo, o excedente do consumidor. A Igreja Universal, por exemplo, parece estar adotando essa política. Com o tempo, segundo Ekelund, essa situação estimulará esses consumidores a buscarem outras religiões mais baratas, que ofereçam serviços religiosos similares. Pode-se observar a veracidade dessa observação ao lembrar o que aconteceu com a Igreja católica e as excessivas cobranças de indulgências, no fim da Idade Média: elas acabaram estimulando a Reforma Protestante. É importante observar, ainda, que, muito provavelmente, a Igreja católica perdeu uma quantidade expressiva de fiéis porque estava oferecendo serviços que não satisfaziam seus consumidores, conforme será tratado no capítulo cinco. Ao que tudo indica, apareceram essas Igrejas neopentecostais oferecendo tais serviços. Por isso, agora, a Igreja católica vem se adaptando aos desejos desses consumidores, hajam vista o processo de Renovação Carismática e a criação da Rede Vida de televisão. Com isso, a competição se acirrará e quem tiver condições de cobrar menos, ou seja, quem tiver custos menores ou produtos melhores estará em vantagem. Mas, com certeza, a perda de fiéis que a 
Igreja católica apresentou nos últimos dez anos não se perpetuará na mesma proporção, devido à mudança estrutural aqui referida.

Ekelund ressalta que a cobrança escandalosa de indulgências na Idade Média, pela Igreja católica, estimulou as pessoas que detinham curvas de demanda inelásticas e viam todo o seu excedente ser expropriado pela Igreja católica a migrarem para o Protestantismo (Ekelund et al., 2002, p.249).

Naquela época, a classe social que possuía curva de demanda inelástica e via todo o seu excedente ser expurgado era a classe dominante, que dependia do apoio da Igreja católica para se manter no poder. No entanto, agora, a classe que parece ter a curva de demanda inelástica é a classe mais baixa, conforme mencionado no parágrafo a seguir, que, à procura da solução para as suas angústias, está disposta a pagar praticamente qualquer preço. Uma situação como essa aumenta os lucros para quem oferece o produto desejado, mas, no médio prazo, estimula o deslocamento da curva de oferta do produto em questão para a direita, ou seja aumenta a oferta, fato que acabará diminuindo a receita dessas Igrejas e, consequentemente, dificultará que se mantenha a expansão dessas Igrejas na velocidade que elas experimentaram na última década.

"O crescimento pentecostal, porém, ocorre de forma muito desigual entre as diferentes classes sociais. Concentra-se nos estratos mais pobres da população. A pesquisa Novo Nascimento, realizada pelo Instituto de Estudos Religiosos - ISER no Grande Rio em meados dos anos 90, revelou que $61 \%$ dos pentecostais recebiam até dois salários mínimos" (Mariano, 1999, p.11).

Como se pôde observar, o mercado de religiões se modificou e se homogeneiza cada vez mais; nesse sentido, caminha para a concorrência perfeita, fato que implica lucro econômico de longo prazo igual a zero e que, portanto, inviabiliza o crescimento exponencial - por tempo indeterminado - que as igrejas neopentecostais vinham experimentando ao longo da última década. 


\subsubsection{O aumento na concorrência indireta}

O problema do aumento da concorrência indireta decorre de um fato bem conhecido e típico do capitalismo industrial, o deslocamento em massa da população do campo para a cidade. Isso teve impactos diretos sobre a Igreja católica no Brasil. Quando a população vivia no campo, a Igreja era a única instituição que articulava a interação entre as pessoas. À medida que a população se deslocou para a cidade, a Igreja católica passou a sofrer uma forte concorrência de bens substitutos, o que pode ser confirmado através da tabela 1, página 27 . Nela, pode-se observar que à medida que a urbanização avança, a porcentagem de pessoas sem religião aumenta, fato que dá indícios da validade da teoria da secularização no Brasil.

"Urbana ou rural, a cristandade tradicional encontra desde já uma forte concorrência da parte de outras religiões. Os clubes, mesmo nas cidades do interior, entram em competição com organizações religiosas, especialmente irmandades e confrarias. Setores inteiros da vida social secularizaram-se. A medicina penetra, o ensino público se estende; a vida política e a vida sindical se organizam de maneira autônoma. As funções terapêutica e lenitiva do catolicismo são denunciadas. Em resumo, acaba-se por colocar seriamente em dúvida a influência real do catolicismo sobre o conjunto da dinâmica social. A antiga função de integração exercida pelo cristianismo é facilmente interpretada em termos de petrificação ou de esclerose da vida social" (Schooyans, 1968, p.58).

Como se pôde observar, a concorrência indireta foi estimulada pela migração do campo para a cidade, pois com a concentração das pessoas nas cidades, a Igreja católica passou a sofrer concorrência de instituições nunca antes enfrentadas, como clubes, irmandades, partidos políticos, sindicatos e outros, ou seja, passou a sofrer a concorrência de bens substitutos, que não existiam no meio rural. Essa substituição faz-se à medida que o tempo é uma variável constante $\mathrm{e}$ a quantidade de instituições que o ser humano passa a freqüentar aumenta, sobrando menos tempo disponível para a prática religiosa. 


\subsection{O estímulo ao sacerdócio católico}

Durante o período imperial e o início da República, era mais ou menos comum que as famílias tradicionais direcionassem ao menos um dos seus filhos ao sacerdócio, dado o prestígio que isso representava. $\mathrm{Na}$ verdade, representava um prestígio similar ao da profissão de médico hoje. No entanto, a sociedade mudou e essa prática parece ser cada vez menos comum. A sociedade parece dar hoje muito mais valor à questão financeira. Nesse sentido, a profissão de médico adquiriu um prestígio muito maior.

Quando se compara a função do padre católico à do pastor protestante, percebem-se vantagens muito superiores para o pastor, considerando o perfil atual da sociedade brasileira. Hajam vista a necessidade do celibato e a remuneração inferior que o padre católico recebe, mesmo considerando os salários indiretos. Nesse sentido, a opção da Igreja católica privilegia a questão da vocação. No entanto, acaba sendo uma das amarras ao crescimento atual da instituição no Brasil, já que as exigências vocacionais da Igreja católica não são congruentes com os interesses da sociedade capitalista moderna, conforme pode-se notar a seguir.

"Os cristãos do interior recém estabelecidos na cidade, custam a sentir a obrigação dominical como um grave dever de consciência. Aliás, devido às distâncias, falta de padres, etc., uma parte ponderável da população é dispensada da prática dominical. Tal é o caso da maior parte dos moradores das grandes fazendas e mesmo, às vezes, de subúrbios. Isso aparece de maneira límpida no ensinamento ordinário dos moralistas mais seguros" (Schooyans, 1968, p.79).

"Muitos padres estrangeiros continuam trabalhando no Brasil. Em 1960 e em 1961, para o clero secular e religioso respectivamente, tinha-se os seguintes dados: no clero diocesano 656 estrangeiros (14,8\%); no religioso 4.008 (56\%); para ambos os cleros, havia um total de 11.587 padres, com 4.664 estrangeiros (40,3\%). Em 1960 ainda, o 
número de padres estrangeiros trabalhando na América Latina era estimado em 12.493 sacerdotes, dos quais 11.075 vindos de 7 países da Europa e os outros dos Estados Unidos e do Canadá. Cerca de 2.800 eram seculares. O Brasil absorvia portanto mais de 1/3 dos padres estrangeiros existentes na América Latina. Atualmente o número de estrangeiros está diminuindo, mas totaliza ainda 35\% do clero no Brasil; no grupo dos religiosos, a porcentagem é bem mais elevada e esteve perto de 55\% em 1965; a do clero secular é de apenas 16,5\%" (Schooyans, 1968, p.47).

"A obsessão do recrutamento vai tão longe que quando uma família religiosa européia encara uma fundação na América Latina, a questão primordial que se coloca é a de saber ‘se há esperança de vocações'. Eis o mundo virado ao avesso! O critério determinante para uma fundação e sua localização não deve ser em primeiro lugar um critério interno, próprio da congregação. Tal critério seria, por assim dizer, subjetivo, centrípeto. A conveniência da congregação não pode ser elemento determinante. Ao contrário, a congregação deve se submeter às necessidades da Igreja local, ouvi-la, dialogar com ela, ver o que tem para lhe oferecer e o que dela pode receber. É preciso deixar de lado qualquer espírito de cálculo, de lucro, toda busca de vantagem ou de comodidades. $\mathrm{Ou}$ melhor, é preciso lembrar que a congregação não desabrochará religiosamente, se não for atenta e submissa às necessidades da comunidade na qual pretende se inserir. Isso implica, algumas vezes, na necessidade de aceitar lucidamente um trabalho sem perspectiva de recompensa, sem que vejam resultados tangíveis a curto e médio prazo" (Schooyans, 1968, p.121).

A imposição dessa armadilha pela própria Igreja católica se transformou em uma amarra ao seu crescimento, provocando a necessidade de importar padres para manter a sua expansão. Solução que atualmente seria mais difícil de adotar, haja vista que as missas não são mais realizadas em latim. 
"A situação é ainda mais trágica se encaramos o futuro. O Brasil conta atualmente com cerca de 12.000 padres, seculares e regulares. Cerca de 1/3 são estrangeiros. Ora, daqui a vinte e cinco anos, dizem-nos os demógrafos, a população terá duplicado. Em consequência, para manter a atual proporção clero/população (1/6.627), seria necessário que dobrassem, em uma geração, os efetivos do clero nacional, ou que triplicassem se a ajuda estrangeira estagnasse ou diminuísse. No estado atual das coisas, nada permite crer nem esperar que isso - nada mais que isso - venha a acontecer. Tudo indica, ao contrário, que a relação atual clero/habitantes tenderá a deteriorar-se" (Schooyans, 1968, p.132).

Como pode ser visto, os dados acima mostram grande preocupação quanto ao crescimento da população e quanto ao crescimento do número de padres. Hoje, pode-se notar que a preocupação tinha fundamento. A distância física da Igreja católica da população, àmedida que as cidades cresceram, causou uma barreira a que essa instituição se expanda. A impossibilidade desse crescimento foi causado, também, pela barreira que a própria Igreja católica se impôs, ao exigir como únicos representantes padres celibatários.

A Igreja católica no Brasil tentou sair dessa amarra, da necessidade de padres celibatários, no final da década de sessenta, e entrou em sério conflito com Roma. Durante essa década, a Igreja enfrentou uma séria crise vocacional e, como remédio para o problema, os bispos brasileiros aprovaram a ordenação de homens casados (Mainwaring, 1989, p.272).

A tabela a seguir mostra que a preocupação de Schooyans fazia total sentido, ou seja, a tendência de se deteriorar a relação população / clero de fato aconteceu ao longo da segunda metade do século $\mathrm{XX}$, e talvez tenha sido um dos motivos que levaram à queda na porcentagem de fiéis católicos. 
Tabela 4. Proporção população clero.

\begin{tabular}{ll}
\hline Ano & Proporção população / clero \\
\hline $1968^{1}$ & $6.627 / 1$ \\
1970 & $7.114 / 1$ \\
1980 & $9.344 / 1$ \\
1991 & $10.200 / 1$ \\
2000 & $10.124 / 1$ \\
\hline
\end{tabular}

Fonte: Centro de Estatística Religiosa e Investigações Sociais - CERIS (2002)

Muito da decadência da relação população / clero talvez possa ser explicado pela queda no estímulo àfunção de padre, que, no passado, era desejada por diversos motivos, como os que já foram ressaltados e os que serão mencionados a seguir.

"Para administrar a igreja em expansão criou-se um corpo de funcionários, o clero. Clero vem do grego kleros e significa possessão, lote de terra. Inicialmente, clero nomeava apenas os administradores dos bens da igreja. Com o tempo, clero passou a ter o significado atual. A força do clero não vinha só da autoridade religiosa, mas também por gerenciar a Igreja - cujas propriedades, a partir do início da Idade Média, eram as maiores do mundo, recebendo rendimentos de feudo, enfiteuse, além dos serviços burocráticos da justiça etc.” (Chiavenato, 2002, p.301-302).

"Por volta do ano 1000, com a expulsão dos bárbaros e a fixação dos povos que comporiam a Europa, a Igreja começou a reorganizar-se. Gregório VII conseguiu que os

\footnotetext{
${ }^{1}$ Schooyans (1968, p.132)
} 
papas fossem eleitos pelo clero, embora ainda restassem pressões feudais. Ele instituiu o celibato e isso afastou os ricos que se tornavam clérigos para fazer carreira política, pois ao ficarem sem descendência deixariam seus bens para a Igreja" (Chiavenato, 2002, p.286-287).

Nesse contexto, e considerando o atual problema dos padres pedófilos e as indenizações milionárias que a Igreja católica vem sendo obrigada a pagar, começa a ganhar força a idéia da retirada da exigência do celibato para os padres. Entretanto, analisando as antigas mudanças estruturais que a Igreja católica adotou, tem-se a noção de que uma medida como essa dificilmente seria adotada no papado atual.

"Para ser padre, é preciso reunir tais e tais aptidões, especialmente no domínio intelectual. É preciso, entre outras coisas, ter frequentado com sucesso um ciclo completo de estudos secundários. Ë preciso também dar garantias que permitam presumir fidelidade ulterior à lei positiva do celibato. Mas, além do casamento não ser, por si mesmo, incompatível com o sacerdócio, o mundo de hoje não tem desenvolvimento cultural suficientemente homogêneo para que se encontre em todas as partes, a mesma proporção de jovens respondendo às exigências atualmente vigentes. Se São Pedro vivesse hoje, teria pouca probabilidade de ser admitido no seminário, não somente porque, tendo uma sogra, devia ser casado, mas também porque, sendo pescador, não devia ser muito letrado" (Schooyans, 1968, p.191).

A solução para o problema acima é sugerida pelo próprio autor e passa pela declericalização do clero, ou seja, pela abertura da função de padre para membros das comunidades, pessoas casadas ou não, mas com perfil para o sacerdócio (Schooyans, 1968, p.207-208).

A própria Igreja católica já adotou essa solução no Brasil, no passado, ao criar nas paróquias rurais, que recebiam padres muito raramente, a figura do rezador. 
"Na ausência do padre, entretanto, os 'rezadores' e 'rezadoras' assumem o papel de liderança religiosa da comunidade. Não há, na verdade, conflito, no mesmo nível, entre o padre e o "rezador". Este é hierarquicamente inferior e sua atuação se restringe a um nível menos sagrado do que a daquele. O templo, dessa forma, é mantido limpo e cuidado, sendo rezados, diariamente, terços e orações" (Camargo, 1971, p.15).

"Os grupos leigos e padres reformistas estavam à frente do processo de renovação eclesiástica, mas os conservadores também apoiavam a abertura da Igreja. A grande maioria do laicado pouco conhecia do ensino oficial católico e a Igreja precisava evangelizar com maior eficácia para competir com outros grupos religiosos. Para os modernizadores, o desejo de estimular uma maior participação leiga era uma forma de aumentar a influência da Igreja nos assuntos temporais e de desenvolver um laicado que ajudasse a evangelizar as massas; nesse sentido, os objetivos eram tradicionais, mesmo que conduzissem a novas práticas. Os modernizadores também esperavam que uma comunidade leiga bem informada ajudasse a resolver os problemas criados pela falta de padres" (Mainwaring, 1989, p.70-71).

É importante lembrar que essa solução foi a adotada pelo Protestantismo na América Latina, que tem tido ótimos resultados, viabilizando o crescimento que estamos vivenciando das Igrejas protestantes no Brasil.

"Um dos segredos do crescimento fulgurante do Protestantismo na América Latina, reside incontestavelmente na capacidade de recrutar e de formar numerosos pastores, originários dos mais diversos meios. Que a Igreja aprenda a lição notadamente aperfeiçoando os métodos tradicionais" (Schooyans, 1968, p.209).

De acordo com o artigo A força do senhor ... (2002), há sete vezes mais pastores protestantes atuando no Brasil que padres, e na maioria das denominações mais recentes esses ministros são formados em apenas alguns meses. Muito logo acabam fundando a própria igreja e 
aumentando o poder dos evangélicos. Na pratica eles seguem aquele famoso incentivo: crescei e multiplicai-vos.

No entanto, é importante lembrar, ainda, que as pessoas têm muito mais estímulo hoje para ser pastor do que para ser padre. Não só pela questão do celibato, mas também pela questão financeira: os salários diretos e indiretos de um pastor transformaram a profissão de pastor em uma profissão muito mais interessante do ponto de vista financeiro do que a de padre.

Tabela 5. Comparação do número de sacerdotes católicos com o de oficiantes protestantes.

\begin{tabular}{lll}
\hline Ano & No. de Oficiantes Protestantes & No. de Sacerdotes Católicos \\
\hline 1968 & 56.704 & 8.338 \\
1977 & 107.593 & 8.631 \\
1991 & $94.350^{2}$ & $14.419^{3}$
\end{tabular}

Fonte: Anuário Estatístico (1968, 1977, 1991)

Como se pode observar o emprego único e exclusivo de padres celibatários se tornou uma amarra ao crescimento físico da Igreja católica brasileira, uma vez que ao longo do tempo o número de padres não cresceu na mesma proporção que a população brasileira. Uma mostra da veracidade dessa afirmação é a necessidade que a Igreja católica sempre teve de importar sacerdotes de outros países, principalmente da Europa, para exercer minimamente suas funções.

\footnotetext{
${ }^{2}$ A Força ... (2002).

${ }^{3}$ Este dado foi retirado do site do instituto Ceris (www.ceris.org.br) e refere-se ao número de presbíteros católicos no ano de 1991.
} 


\subsection{Questões de cunho financeiro e a Igreja católica}

Ao que tudo indica, os recursos financeiros necessários para a manutenção e a expansão da Igreja católica pesam nas decisões dessa instituição. Será possível observar, a seguir, que esse aspecto de cunho secular acaba influenciando as decisões da Igreja católica, não obstante o seu desejo que tal não ocorra.

De acordo com o artigo Escândalos levam papa a aceitar renúncia do cardeal de Boston ... (2002), a questão financeira se mostrou especialmente importante na decisão tomada pelo cardeal de Boston, Bernard Law, ao declarar a quebra financeira da arquidiocese de Boston, quando 450 pessoas solicitaram judicialmente quantias milionárias de indenização por abuso sexual.

O "Jornal Nacional", da Rede Globo de televisão, noticiou o assunto descrito no parágrafo anterior como se a decisão, da arquidiocese de Boston, fosse uma estratégia para o não pagamento das possíveis indenizações. Essa decisão da arquidiocese de Boston demonstra a influência de uma questão secular sobre as decisões da Igreja católica. Entretanto, é importante ressaltar que o Vaticano ainda não se posicionou sobre a decisão de Bernard Law.

A questão dos recursos financeiros também toma proporções importantes nas decisões da Igreja católica brasileira. Essa instituição chegou a passar por cima de suas próprias convicções para apoiar o governo de Getúlio Vargas. Segundo Mainwaring, apesar do aspecto extremamente autoritário desse governo, em desacordo com a doutrina da Igreja católica, que privilegia a individualidade das pessoas, a instituição passou por cima disso tudo para apoiar esse governo e continuar a ser beneficiada financeiramente ${ }^{4}$ por ele (Mainwaring, 1989, p.47-49).

"Através de seu acordo com Vargas, a Igreja havia conservado o domínio do sistema educacional e seu status de instituição religiosa privilegiada dentro da sociedade. Os 
governos democráticos do período de 1945 - 1964 tentaram conquistar o apoio da Igreja e em troca concederam alguns favores, mas a negociação não era tão favorável nem estável como o fora sob o governo de Vargas" (Mainwaring, 1989, p.54).

Com o surgimento da ditadura militar, esse relacionamento privilegiado entre a Igreja católica e o Estado foi se reduzindo até desaparecer, e o que se colocou no lugar foi um relacionamento conflituoso entre o Estado e a Igreja católica, posicionando-a, inclusive, mais à esquerda.

Com tal mudança de regime político, a Igreja católica brasileira começou a se posicionar de forma mais coerente com seus ideais e passou a criticar fervorosamente a postura violenta dos militares, a concentração de renda que estava sendo gerada no governo militar e começou a pregar uma transformação social radical no sistema capitalista (Mainwaring, 1989, p.122).

Mas essa ruptura com o Estado não foi tão natural assim, pois a Igreja, mesmo com o golpe militar de 1964, fez um esforço enorme para manter um bom relacionamento com o Estado, apesar de ele contradizer o ideal cristão. Isso ocorreu, muito provavelmente, devido ao receio de perder as benesses financeiras conquistadas durante o governo de Getúlio Vargas. Mas, com o passar do tempo, a Igreja passou a ser perseguida pelo Estado, haja vista a oposição que alguns grupos de dentro da instituição faziam contra o governo militar. Com isso, esse apoio ficou insustentável (Mainwaring, 1989, p.161).

Outro bom exemplo da influência da questão financeira sobre a Igreja católica foi o Movimento de Educação de Base - MEB que tinha como objetivo levar uma educação de base para as regiões mais pobres do Brasil. Esse projeto surgiu no governo de Jânio Quadros e teve suporte financeiro do mesmo, sendo o executor a Igreja católica brasileira. Com o governo militar, o suporte financeiro do Estado foi abandonado e o projeto morreu (Mainwaring, 1989, p.88-89).

\footnotetext{
${ }^{4}$ Os benefícios financeiros concedidos pelo governo Vargas foram: ajuda financeira para as escolas católica,
} 
"Os bispos viam o Estado como um agente para a mudança social e a Conferência Nacional dos Bispos do Brasil - CNBB apoiou o governo nos últimos anos populistas (1956 - 1963). Vários projetos sociais da Igreja eram empreendidos em colaboração com o Estado. O Estado financiou, por exemplo, o Movimento de Educação de Base. A Superintendência de Desenvolvimento do Nordeste - SUDENE, criada no final da década de 50, era um produto da cooperação entre a Igreja e o Estado" (Mainwaring, 1989, p.76).

Devido ao tamanho e à abrangência da Igreja católica, a questão da administração dos seus recursos financeiros se transformou em algo essencial para sua sobrevivência. $O$ fato é reconhecido até por teólogos, como será visto a seguir. Isso influencia o direcionamento que a instituição toma, conforme pode ser observado ao analisar-se a evolução da postura da Igreja católica na administração de suas instituições, tais como, escolas, universidades e hospitais.

"Mais uma vez, a comparação com o que passa no domínio econômico é esclarecedora. Para decolar, a economia brasileira pôde contar com a ajuda exterior complementar, especialmente em mão-de-obra e capital. Da mesma maneira, para voar com suas próprias asas, o Catolicismo brasileiro, atualmente desprovido de padres e de recursos, deve poder contar com uma ajuda exterior suficiente e esclarecida. Essa ajuda aplicar-seá de modo a apoiar as forças dinâmicas da Igreja local. Deve visar a aproximação do dia em que, tendo atingido um certo limiar, a Igreja no Brasil terá imprimido a si mesma um ritmo de desenvolvimento em harmonia com as exigências da situação nacional" (Schooyans, 1968, p.150).

A influência dos recursos financeiros nas decisões da Igreja católica é apontada por Woodberry como algo comum desde o período colonial, quando as missões religiosas, que tinham como objetivo a conversão dos nativos, já viviam na dependência dos governos coloniais. Devido a esse fato, tinham grande dificuldade de contestar as atitudes desses governos, mesmo 
quando elas eram totalmente contra determinada decisão. Fato que, segundo Woodberry, era mais difícil de acontecer nas colônias inglesas, compostas de missões protestantes, que se auto financiavam e, portanto, tinham mais independência em relação ao Estado colonial inglês (Woodberry, 2002, p.12-13).

Outro aspecto que ressalta a influência de aspectos financeiros na Igreja católica é o fato de, no passado, ela ter optado por um padrão suntuoso para suas igrejas, nitidamente mais custoso do que o das suas concorrentes atuais. $\mathrm{O}$ fato claramente dificulta a sua expansão física, pois o custo da manutenção dessas igrejas poderia estar sendo direcionado para essa expansão. Outra barreira à expansão, da Igreja advém da combinação entre o crescimento das cidades e a busca da comodidade: a distância das igrejas católicas dos bairros mais afastados se torna um dos fatores limitantes ao seu crescimento. Uma pequena amostra do alto custo da manutenção das igrejas católicas pode ser observado no excerto que segue, transcrito do jornal "O Estado de São Paulo", onde se menciona a ajuda do Banco Nacional de Desenvolvimento Regional BNDES para a restauração das igrejas católicas.

De acordo com o artigo Restauro devolve brilho a igrejas do Rio ... (2003), o BNDES começou a investir nessa área em 1997 e já gastou R 41 milhões em 71 obras espalhadas pelo país. O Rio ficou com $20 \%$ dessa quantia, distribuída em 15 projetos com valores variáveis entre R \$ 4,5 milhões, gastos na Igreja da Ordem Terceira de São Francisco, e os R \$ 167 mil que serão empregados na restauração do teto da sacristia do Convento Santo Antônio, também no centro.

A tabela a seguir, demonstra o fato de, ao longo da segunda metade do século $\mathrm{XX}$, a distância entre o número de templos católicos e protestantes ter cada vez mais diminuído. Observação que parece indicar dificuldade de expansão da Igreja católica nos moldes suntuosos que ela estabeleceu para si. Enquanto isso, as igrejas protestantes, que não seguem um padrão de suntuosidade, estão cada vez mais próximas de seus fiéis, ao menos fisicamente. 
Tabela 6. Comparação do número de locais de culto da igreja católica e das igrejas protestantes.

Ano

Locais de Culto das Igrejas

Protestantes

1968

1977

1979

1991

38.857

42.660

45.286

$\ldots$
24.130

33.848

38.300

$75.593^{5}$

Fonte: Anuário Estatístico (1968, 1977, 1979, 1991)

O próximo parágrafo refere-se a dados da década de 1990, para municípios do Rio de Janeiro. Através desse parágrafo, pode-se ter uma noção melhor da situação dos templos católicos e protestantes.

“Somente nos municípios de Duque de Caxias e São João do Meriti pode-se traçar uma comparação rigorosa entre o número de templos evangélicos e o de comunidades católicas. A desvantagem da Igreja Católica superou suas expectativas mais pessimistas: possuía 237 comunidades de culto, menos da metade dos 506 templos crentes" (Mariano, 1999. P.11).

A influência dos recursos financeiros sobre a expansão ou a retração dos serviços prestados por instituições de ensino e de saúde católicas pode ser observada nos três parágrafos

\footnotetext{
${ }^{5}$ Este dado foi retirado do artigo A força ... (2002) e refere-se ao número de templos das principais Igrejas protestantes.
} 
que seguem. Esse é um dos motivos que, cada vez mais, têm impacto sobre as decisões que as instituições tomam dentro da sociedade, inclusive a Igreja católica.

"Havemos de entender facilmente que os colégios católicos não poderão jamais pretender ser tão numerosos quanto os do Estado. Os poderes públicos dispõem de recursos financeiros com os quais não podemos rivalizar" (Schooyans, 1968, p.145).

"Há também grande investimento em educação. A média de leitura dos evangélicos brasileiros gira em torno de seis livros por ano - o dobro da média nacional. As denominações evangélicas administram quase 1000 escolas no Brasil, com uma clientela de 740.000 alunos. No tradicional ensino católico, o que se vê é encolhimento. A CNBB divulgou recentemente que 130 escolas católicas de ensino fundamental e médio fecharam as portas nos últimos cinco anos" (A Força ... 2002, p.95).

A questão financeira também influencia as decisões das universidades católicas, que, em 1965, eram mais baratas do que as particulares comuns, segundo Schooyans (1968). Mas hoje, cobram o mesmo preço, ou muitas vezes um preço mais alto do que muitas universidades particulares comuns. A PUCCAMP e a PUC-SP, por exemplo, são universidades católicas mais caras do que várias universidades particulares.

A dificuldade financeira que as universidades católicas enfrentavam nas décadas de 1960, 1970 e 1980, determinou que se reduzisse o número total de alunos universitários atendidos pelas universidades católicas. Pode-se levantar a hipótese de que tal fato, em conjunto com a adequação de suas mensalidades à realidade do mercado, melhorou a situação financeira da maioria das universidades católicas ao longo da década de 1990.

“Em 1962, a população universitária total era de 88.521 alunos, dos quais 19.946 (i.e $22,5 \%$ ) nos estabelecimentos católicos. Sabemos, por outro lado, que no mesmo ano 40\% dependiam do ensino particular, e que para 1965 a porcentagem era de $43 \%$. Dos 155.751 matriculados, tínhamos portanto cerca de 66.985 nos estabelecimentos 
particulares. Supondo que a proporção de $22,5 \%$ se tenha mantido constante, 35.050 estudantes seriam atualmente atendidos pelas faculdades católicas. Passando de 68.575 a 120.731, o número de estudantes não atendidos pelas faculdades católicas teria portanto conhecido, em números absolutos, um acréscimo de 80\% em 1962 e 1965. É provável, porém, que o acréscimo real seja maior ainda e que a desproporção continue se acentuando. De fato, entre 1962 e 1965 passou-se de 134 faculdades católicas para 146, o que representa um acréscimo de $9 \%$. Nada indica que em tão curto espaço as faculdades católicas se tenham equipado para atender, sempre na nossa hipótese, a uma demanda de 15.104 vagas novas, representando um aumento de $75 \%$ em relação com estudantes matriculados em 1962"'(Schooyans, 1968, p.228).

"Sob o aspecto financeiro, são por demais conhecidas as condições precárias das faculdades católicas. Mas quase não se divulga nada de preciso a esse respeito. Poucas são as instituições que possuem um patrimônio. Raros são os professores de tempo integral. A retribuição se calcula quase sempre por aulas dadas. Há alguns anos, certas faculdades pagam cerca de 2 dólares a aula. Agora estão pagando de 3 a 5 dólares. Quando às despesas anualmente renováveis, é difícil avaliá-las. Baseando-se sobre dados passíveis de revisão e fragmentários, pode-se estimar que um estudante custa, por ano, cerca de 200 dólares às universid ades católicas” (Schooyans, 1968, p.228).

A questão financeira acaba sendo uma amarra ao seu crescimento, também porque, a Igreja católica adota uma posição extremamente reacionária na sua forma de administrar-se. Isto pode ser observado a seguir.

"A igreja vem sendo administrada desde a fundação por uma burocracia centralizada e autoritária. Esse autoritarismo produziu atitudes conservadoras ou reacionárias, criticadas pelos historiadores e alguns teólogos católicos" (Chiavenato, 2002, p.304). 
Esse tipo de atitude aparentemente permeia toda a instituição, inclusive na sua forma de administração. Em algumas situações, isso pode ser positivo e necessário, mas a sua administração deve buscar o rompimento com essa atitude e ser a mais profissional possível, de forma a viabilizar a sua expansão física.

A estratégia descrita no parágrafo anterior é adotada pelas igrejas que mais cresceram nos últimos anos, as neopentecostais, e é apontada pelos especialistas como um dos principais motivos do seu crescimento (Mariano, 1999, p.27-35).

A fase de maior crescimento da Igreja católica está associada a conquistas seculares, conforme afirma Chiavenato, fato que dá suporte à afirmação acima.

"A partir dessas vitórias e da estabilização administrativa, a Igreja cresceu economicamente, assimilando bens materiais (terras, conventos, aldeias, escravos) e passou a ser produtora e monopolizadora da cultura e das artes em longos períodos" (Chiavenato, 2002, p.276).

Como pode ser observada, a administração dos recursos financeiros detém influência direta sobre a expansão ou a retração da Igreja católica. Essa constatação permite acenar que uma administração, denominada enxuta ${ }^{6}$, seria a solução para o aumento do nível de influência da instituição sobre a sociedade. É preferível uma administração profissional, inclusive cobrando o necessário para a sobrevivência e a expansão de seus colégios e hospitais, à dependência

\footnotetext{
${ }^{6} \mathrm{~A}$ administração enxuta é o modelo administrativo, considerado dos mais eficientes, porque combina as vantagens das produções artesanais e em massa (criada por Henry Ford), evitando os altos custos da primeira e a rigidez da última. A administração enxuta emprega equipes de trabalhadores multiqualificados em todos os
} 
financeira de terceiros, haja vista que essa situação causa submissão, como se pôde observar na relação entre o Estado e a Igreja católica no período imperial.

A influência que os recursos financeiros acabam exercendo sobre a Igreja católica pode ser observada em diversas passagens de sua história. Com o objetivo de ressaltar essa influência, serão descritas a seguir as passagens tratadas nesse capítulo: 1) o apoio a Getúlio Vargas apesar de muitas de suas idéias serem contrárias à doutrina da Igreja católica; 2) o Movimento de Educação de Base - MEB projeto da Igreja católica que só foi viabilizado devido à ajuda financeira do governo de Jânio Quadros; quando essa ajuda cessou, o projeto ruiu; 3) a estrutura física suntuosa das igrejas católicas emperram o seu crescimento físico; 4) a necessidade de adequação dos preços cobrados pelas universidades católicas à realidade do mercado.

níveis da organização, além de máquinas altamente flexíveis e cada vez mais automa tizadas, para produzir imensos volumes de produtos de ampla variedade. 


\section{A SITUAÇÃO ATUAL DA IGREJA CATÓLICA BRASILEIRA}

A intenção deste capítulo é utilizar a análise dos principais estudiosos do assunto "economia e religião" e também a análise dos impactos de questões seculares sobre a Igreja católica brasileira, no período republicano, para ressaltar alguns possíveis direcionamentos dessa instituição, principalmente quanto à perda expressiva de fiéis que ela vem experimentando.

\subsection{A redução do número de fiéis: contribuição para a discussão atual}

Esse trabalho pode contribuir para a discussão que existe atualmente, sobre os motivos que estão levando a Igreja católica brasileira a perder quantidades expressivas de fiéis. Tal discussão intensificou-se após a divulgação dos dados do Censo de 2000, onde foi detectado que a porcentagem de fiéis católicos se reduziu de $83 \%$ da população para $73 \%$, na última década. Este capítulo não tem a pretensão de esgotar a discussão atual e responder de forma definitiva por que a Igreja católica tem experimentado uma queda expressiva na porcentagem de fiéis nas últimas décadas. Contudo, pretende-se amadurecer a discussão e apresentar por que algumas justificativas fazem mais sentido do que outras.

A discussão atual está calcada em dois motivos centrais, que justificariam o problema por que passa a Igreja católica brasileira: 1) a rápida urbanização do país, que causou mudanças de comportamento na população, com reflexos na área religiosa; e 2) a exagerada politização da 
Igreja católica no Brasil durante os últimos 30 anos, tese defendida pelo bispo diocesano de Jundiaí, interior de São Paulo, D. Amaury Castanho (Arruda, 2002).

O presente trabalho mostra, através de Barro, Camargo e Weber, que a urbanização contribui para a redução da religiosidade em geral, e não somente do Catolicismo. Portanto, através desses autores, pode-se concluir que não foi a urbanização que reduziu o número de fiéis católicos como um todo. Contudo, não se pode afirmar que o segundo motivo, a politização da igreja católica, tenha determinado essa queda no número de fiéis.

D. Amaury defende que projetos como as Comunidades Eclesiais de Base - CEBs que possuem enfoques políticos de esquerda e a extinção do Catolicismo popular, que se baseia na imagem dos santos e nas festas populares ${ }^{7}$, apesar de terem sido constituídos para as classes de baixa renda, obtiveram, como resultado, uma queda ainda maior no número de fiéis junto a essa classe. D. Amaury lembra que isso ocorreu porque as pessoas estão buscando projetos de fé, e não projetos políticos de esquerda. Por outro lado, sociólogos do Centro de Estatística Religiosa e Investigações Sociais - CERIS possuem opiniões opostas às de D. Amaury e ressaltam que, se não fossem as CEBs, a perda de fiéis seria ainda maior e apontam, como argumento, o fato de que estados onde as CEBs se multiplicaram ocuparam os dez primeiros lugares no ranking das populações católicas (Arruda, 2002).

Neste trabalho, pode-se observar, através das idéias de Mainwaring, o desdém da Igreja católica para com o Catolicismo popular, e também o fato de que esse desprezo só diminuiu quando outras religiões começaram a ganhar adeptos exatamente porque privilegiaram o Catolicismo popular. De fato, o desprezo ao Catolicismo popular, agregado a um enfoque que parece não preocupar tanto as massas, pode ter sido uma das causas da redução na porcentagens de fiéis católicos (Mainwaring, 1989, p.50-53).

\footnotetext{
${ }^{7}$ Essas políticas são denominadas secularização e são imposições da Igreja Católica Européia.
} 
Mainwaring dá suporte à teoria de D. Amaury e complementa afirmando que a politização e a secularização da Igreja, que têm como objetivo combater o Catolicismo popular, causou uma queda no número de fiéis católicos na década de setenta (Mainwaring, 1989, p.196).

Outros analistas que compartilham das idéias de D. Amaury ressaltam, ainda, que o projeto responsável pelo relativo sucesso em estancar a perda de fiéis é a Renovação Carismática, e não as CEBs, e lembram que o sucesso da Renovação Carismática é a ênfase, não em questões sociais e políticas, mas no Catolicismo popular, tratando de questões como a crença em milagres (Arruda, 2002).

Contudo, conforme foi observado no parágrafo anterior, o sucesso da Renovação Carismática em expandir o número de fiéis católicos tem sido relativo. Conforme pode ser observado a seguir, ou na tabela 3, da página 46.

"Paradoxalmente, o que mais mudou no Brasil com o crescimento da legião evangélica foi a Igreja Católica. De um lado, surgiu a Renovação Carismática, para revigorar os aspectos místicos e milagrosos da fé. De outro, os padres - cantores saíram atrás de fiéis e compradores de CDs. Na mídia, a Igreja fincou uma bandeira em tempo recorde, criando a Rede Vida de radio e TV, que cobre todo o território nacional. Os resultados, porém, estão longe dos esperados" (A Força ... 2002, p.95).

Os pontos discutidos até aqui indicam que os argumentos de D. Amaury possuem embasamentos teóricos mais consistentes. Contudo, é possível que este trabalho possa agregar fatos novos à discussão, pois ela desconsidera um aspecto que se acredita ser importante e decisivo na determinação da quantidade de fiéis que a Igreja católica tem perdido neste último século, que é a questão financeira, apresentada na estrutura física de seus custos, na mão-deobra utilizada pela instituição e os demais aspectos discutidos neste trabalho.

Com isso, não se está querendo dizer que projetos como a Renovação Carismática não têm influência sobre o desenvolvimento da quantidade de fiéis da Igreja católica brasileira, mas 
que as questões financeiras, que não estão sendo levadas em consideração na discussão apresentada, têm influência sobre os aspectos aqui tratados.

Objetiva-se terminar este capítulo levantando a hipótese de que um tratamento mais enxuto da administração da Igreja católica brasileira, em todos os níveis, seria uma saída para a ampliação do seu número de fiéis, ou pelo menos, para a redução das perdas que vem apresentando atualmente. Isso se justifica pelos motivos discutidos no capítulo quatro, itens três e quatro.

É interessante observar, ainda, que se fala tanto da influência do secular sobre a Igreja católica, e da manutenção e da ampliação da quantidade de fiéis como uma das principais preocupações da Igreja, mas apesar da combinação desses dois fatores, pouco se discute sobre a não secularização da sua administração, que seria uma decisão natural para quem almeja atingir esse objetivo. 


\section{OBSERVAÇÕES FINAIS}

Neste capítulo, serão ressaltados os pontos mais importantes tratados ao longo do trabalho, e que visam a atingir nosso objetivo - analisar o comportamento da Igreja católica no Brasil, como instituição, frente a acontecimentos seculares, principalmente de cunho político e econômico.

Os primeiros estudiosos sobre o tema, Mill, Marx, Engels, Troeltsch e Marshall, não tinham como preocupação central, em seus trabalhos, desvendar a relação entre economia e religião. Portanto, limitavam-se a concluir que havia uma relação de interferência da religião sobre a economia. Dentre os autores mais atuais, poucos, como Voz e Falise, estudam o tema e não entram na discussão Capitalismo x Protestantismo. Existem outros autores contemporâneos, como Barro e Iannaccone, que enfocam seus estudos na questão da secularização e vêm encontrando indícios de veracidade nessa tese, ou seja, à medida que a sociedade evolui economicamente, a religiosidade ${ }^{8}$ tende a se reduzir. É obvio, no entanto, que, dentre as várias conclusões descritas neste trabalho, há variações em torno dessa confirmação. Dos críticos às idéias de Weber, como Sombart, Fanfani, Samuelsson, Robertson e mais recentemente Lima, podemos dizer que algumas críticas têm fundamento e outras não. No entanto, a idéia de que o Protestantismo liberou a mente das pessoas para pensar de forma capitalista, quando do

\footnotetext{
${ }^{8}$ A definição de religiosidade varia de autor para autor, alguns interpretam como religiosidade frequência à igreja; outros, a porcentagem de pessoas que declaram ter uma religião.
} 
surgimento do capitalismo industrial, coisa que o Catolicismo não fez, não consegue ser derrubada por nenhum deles.

Os autores contemporâneos que estudam empiricamente o assunto em pauta, principalmente Guiso, Woodberry e McCleary, estão chegando a resultados que dão suporte às idéias de Weber.

Após analisar as idéias dos críticos e dos simpatizantes das idéias de Weber, é possível concluir que, apesar das falhas na obra de Weber, ela não consegue ser totalmente contestada e a idéia central de que o capitalismo industrial foi impulsionado pelo Protestantismo, e não pelo Catolicismo, se impõe.

Quando o assunto é a secularização da Igreja católica, obtivemos fortes indícios teóricos e empíricos de que a religiosidade, de forma geral, se reduz com o desenvolvimento do capitalismo, ou seja, a tese da secularização se mostra consistente até o presente momento.

Ao tentar esclarecer os motivos que levaram ao rompimento entre o Estado e a Igreja católica brasileira, durante a transição do sistema monárquico para o republicano, encontramos motivos ideológicos e financeiros, tais como: a perda da função que a Igreja católica exercia na monarquia; a questão da liberdade individual e do laicismo dos Estados republicanos e, por último, o alívio financeiro para o Estado republicano, decorrente da separação entre ele e a Igreja católica, haja vista que o Estado monárquico ajudava financeiramente esta instituição. Vale a pena lembrar ainda que, no Brasil, a dissociação entre o Estado e a Igreja católica não parece se relacionar com um fato muito comum na Europa, que se trata de capitalistas puritanos chegarem ao poder através do sistema republicano e exigirem a separação entre Estado e a Igreja católica, uma vez que essa instituição tendia a atrapalhar o desenvolvimento pleno do capitalismo, conforme ressaltado por Weber e outros.

Analisando a relação da Igreja católica brasileira com o Estado monárquico e com o Estado republicano, pudemos perceber que, no período monárquico, o Estado brasileiro 
financiava a Igreja católica e, devido a tal fato, sentia-se no direito de interferir nesta instituição. Isso acabava causando uma série de desentendimentos entre as duas instituições. Entretanto, quando da separação, a Igreja católica pediu a todos que lutassem contra tal situação. Com o período republicano e a separação entre o Estado e a Igreja católica, o relacionamento conflituoso entre as duas instituições terminou e esta ficou livre para se preocupar mais intensamente com os aspectos doutrinários. No entanto, seu poder de mercado se reduziu e isso se refletiu na expansão de Igrejas concorrentes e na queda da porcentagem de fiéis católicos.

Ao abordar o problema do aumento da concorrência, enfrentado atualmente pela Igreja católica brasileira, notamos que essa concorrência se intensifica tanto de forma direta como indireta. Com a concentração das pessoas nas cidades, a Igreja católica passou a sofrer uma concorrência mais intensa de instituições como clubes, irmandades, partidos políticos, sindicatos e outros, ou seja, passou a sofrer concorrência de bens substitutos, marginais no meio rural. Denominamos esse tipo de concorrência de indireta. Quanto à concorrência direta, ela também aumentou, e isso pode ser observado e deve-se, em grande parte, ao término da situação privilegiada que a Igreja católica detinha ao usufruir da situação de única igreja estatal. Com o fim desse benefício, surgiram diversas Igrejas buscando satisfazer os desejos dos fiéis católicos descontentes e, com isso, se estabeleceram no mercado. A Igreja católica, por outro lado, demorou a se adaptar e a dar atenção a esses desejos. Com isso, ela acabou perdendo espaço no mercado de fiéis e diversas outras Igrejas se estabeleceram, como já foi ressaltado.

O emprego único e exclusivo de padres celibatários tornou-se uma amarra ao crescimento físico da Igreja católica brasileira, uma vez que, ao longo do tempo, o número de padres não cresceu na mesma proporção que a população. Uma amostra dessa amarra é o fato de que a Igreja católica sempre teve que importar sacerdotes de outros países, principalmente da Europa, para exercer minimamente suas funções.

Quando observamos a influência de aspectos financeiros sobre a Igreja católica, pudemos notar que eles exercem uma influência direta sobre a expansão ou a retração dela. Essa 
constatação permite-nos acenar que uma administração enxuta seria a solução para o aumento da expansão física dessa instituição. A influência que questões de cunho financeiro acabaram exercendo sobre a Igreja católica pode ser observada em diversas passagens de sua história. Com o objetivo de ressaltar essa influência, citamos, a seguir, algumas dessas passagens: 1) o apoio a Getúlio Vargas, apesar de muitas de suas idéias serem contrárias à doutrina da Igreja católica; 2) o Movimento de Educação de Base - MEB - projeto da Igreja católica que só foi viabilizado devido à ajuda financeira do governo de Jânio Quadros; quando essa ajuda cessou, o projeto ruiu; 3) a estrutura física suntuosa das igrejas católicas emperram o seu crescimento físico; 4) a necessidade de adequação dos preços cobrados pelas universidades católicas à realidade do mercado.

Por último, vale a pena notar que a presente dissertação buscou analisar o comportamento da Igreja católica brasileira, como instituição, frente a questões seculares, principalmente de cunho econômico e político. Para isso, utilizourse o conhecimento de especialistas em cada uma das áreas analisadas. Contudo, um trabalho dessa natureza não pretende fazer observações irrefutáveis. É importante ressaltar que, considerando o fato, estudos futuros sobre os temas aqui abordados passam a ser extremamente bem-vindos e dignos de recomendação. 


\section{REFERÊNCIAS BIBLIOGRÁFICAS}

A FORÇA do senhor. Veja, v.35, n.26, p.88-95, 2002.

ANUÁRIO ESTATÍSTICO DO BRASIL - 1968, 1977, 1991.

ARRUDA, R. Perda de fiéis faz católicos questionarem politização. Estado de São Paulo. Caderno Nacional, São Paulo, 02 jun. 2002.

BARRO, R.J.; MACCLEARY R.M. Religion and economy in an internacional panel. Cambridge: Harvard University, 2002. p.69. (PRPES Working Papers) http://www.wcfia.harvard.edu/programs/prpes/ (18 Nov. 2002)

BIRNBAUM, N.; GERTRUD, L. Sociology and religion. Upper Saddle River: Prentice-Hall, 1969. 452p.

CAMARGO, C.P.F. de. Igreja e desenvolvimento. São Paulo: Editora Brasileira de Ciências, 1971. 218p.

CENSO DEMOGRÁFICO - 1872, 1890, 1940, 1950, 1960, 1970, 1980, 1991, 2000.

CENTRO DE ESTATÍSTICA RELIGIOSA E INVESTIGAÇÕES SOCIAIS - CERIS. Departamento de estatística e pesquisas sociológicas. http://www.ceris.org.br/estatistica/quadro_02a.htm (30 jul. 2002)

CHARBONNEAU, P.E. Cristianismo, sociedade e revolução. São Paulo: Herder, 1967. $584 \mathrm{p}$.

CHIAVENATO, J.J. Religião: da origem à ideologia. Ribeirão Preto: Funpec, 2002. 360p. 
COSTA, E.V. da. Da monarquia à república:momentos decisivos. São Paulo: Grijalbo, 1977. $326 p$.

DICKINSON, R. Igreja e desenvolvimento. São Paulo: Quatro Artes, 1969. 196p.

DUSSEL, E. História da igreja latino americana: (1930 a 1985). São Paulo: Paulus, 1989. 99p.

EKELUND, R.B.; HÉBERT, R.F.; TOLLISON, R.D. An economic analysis of the protestant reformation. Journal of Political Economy, v.110, n.3, p.646-671, 2002.

ESCÂNDALOS levam papa a aceitar renúncia do cardeal de Boston. O Estado de São Paulo. Caderno Geral, São Paulo, 14 dez. 2002. p.A-20.

FALISE, M. Economia e cristianismo. São Paulo: Ibrasa Champagnat, 1991. 180p.

FANFANI, A. Catolicismo y protestantismo en la genesis del capitalismo. Madrid: Rialp, 1953. 330p.

FARIA, A. de. Mauá: Irenêo Evangelista de Souza, barão e visconde de mauá 1813 - 1889. Rio de Janeiro: Paulo, Pongetti \& Cia., 1926. 604p.

FUSFELD, D.R. A era do economista. Trad. de F.D. Waltenberg. São Paulo: Saraiva, 2001. $356 p$.

GUISO, L.; SAPIENZA, P.; ZINGALES, L. People's opium ? the economic effect of religion. Cambridge: Harvard University, 2002. 62p. (PRPES Working Papers) http://www.wcfia.harvard.edu/programs/prpes/ (14 June 2002)

IANNACCONE, L.R. Looking backward: a cross - national study of religious trends. Cambridge: Harvard University, 2002. 34p. (PRPES Working Papers) http://www.wcfia.harvard.edu/programs/prpes/ (14 June 2002)

JONES, D.T.; ROOS, D.; WOMACK, J.P. A máquina que mudou o mundo. Trad. de I. Korytowski. Rio de Janeiro: Campus, 1992. 347p.

LIMA, C.L. Teologia de mercado: uma visão da economia mundial no tempo em que os economistas eram teólogos. Bauru: Edusc, 2001. 316p.

LUSTOSA, O. de F. A igreja católica no Brasil república. São Paulo: Paulinas, 1991. 180p. 
MAINWARING, S. A igreja católica e a política no Brasil: (1916 - 1985). São Paulo: Brasiliense, 1989. 300p.

MANKIW, N.G. Introdução à economia: princípios de micro e macroeconomia. Trad. de M.J.C. Monteiro. Rio de Janeiro: Campus, 2001. 831p.

MARIANO, R. Neopentecostais: sociologia do novo pentecostalismo no Brasil. São Paulo: Loyola, 1999. 246p.

MCCLEARY, R.M. Salvation, damnation and economic incentives. Cambridge: Harvard University, 2002. 48p. (PRPES Working Papers) http://www.wcfia.harvard.edu/programs/prpes/ (18 Nov. 2002)

PEREIRA, N. Conflitos entre a igreja e o estado no Brasil. Recife: Massangana, 1982. $332 p$.

RESTAURO devolve brilho a igrejas do Rio. O Estado de São Paulo. Caderno Cidades, São Paulo, 22 jun. 2003. p.C4-C5.

RIBEIRO, F. D. Para uma análise crítica da idéia de desenvolvimento. São Paulo, 2001. 232p. Dissertação (M.S.) - Faculdade de Filosofia, Letras e Ciências Humanas - Universidade de São Paulo.

RIBEIRO, R. Antropologia da religião e outros estudos. Recife: Massangana, 1982. 310p.

ROBERTSON, H.M. Aspects of the rise of economic individualism a criticism of Max Weber and his school. New York: A. M. Kelley, 1959. 223p.

RODRIGUES, A.M.M. A igreja na república. Brasília: Universidade de Brasília, 1981. 185p.

SAMUELSSON, K. Religion and economic action. Estocolmo: Alb. Bonniers Boktryckeri, 1961. $157 \mathrm{p}$.

SANDRONI, P. Novíssimo dicionário de economia. São Paulo: Best Seller, 2001. 646p.

SCHOOYANS, M. O desafio da secularização. São Paulo: Herder, 1968. 319p.

SOMBART, W. The jews and modern capitalism Illinois: The Free Press, 1951. 402p. 
TORRES, J.C. de O. Histórias das idéias religiosas no Brasil. São Paulo: Grijalbo, 1968. $324 p$.

VOS, H.; VERVIER, J. Utopia cristã e lógica econômica. Petrópolis: Vozes, 1997. 212p.

WEBER, M. A ética protestante e o espírito do capitalismo. São Paulo: Pioneira, 1967. $233 p$.

WOODBERRY, R.D. Democratization in post-colonial societies: the long - term influences of religion and colonial governments. Cambridge: Harvard University, 2002. 45p. (PRPES Working Papers) http://www.wcfia.harvard.edu/programs/prpes/ (18 Nov. 2002) 